\title{
Review Article \\ The Role of Physical Techniques on the Preparation of Photoanodes for Dye Sensitized Solar Cells
}

\author{
Shideh Ahmadi, ${ }^{1}$ Nilofar Asim, ${ }^{2}$ M. A. Alghoul, ${ }^{2}$ F. Y. Hammadi, ${ }^{2}$ Kasra Saeedfar, ${ }^{3,4}$ \\ N. A. Ludin, ${ }^{2}$ Saleem H. Zaidi, ${ }^{2}$ and K. Sopian ${ }^{2}$ \\ ${ }^{1}$ NOVITAS, School of Electrical and Electronic Engineering, Nanyang Technological University, Singapore 639798 \\ ${ }^{2}$ Solar Energy Research Institute, Universiti Kebangsaan Malaysia, 43600 Bangi, Selangor, Malaysia \\ ${ }^{3}$ School of Chemical Science \& Food Technology, Faculty of Science and Technology, Universiti Kebangsaan Malaysia, \\ 43600 Bangi, Selangor, Malaysia \\ ${ }^{4}$ Department of Chemistry, Faculty of Science, K. N. Toosi University of Technology, Tehran 15875-4416, Iran
}

Correspondence should be addressed to Nilofar Asim; asimnilofar@gmail.com and M. A. Alghoul; dr.alghoul@gmail.com

Received 14 August 2013; Revised 3 December 2013; Accepted 17 December 2013; Published 9 February 2014

Academic Editor: Mahmoud M. El-Nahass

Copyright (C) 2014 Shideh Ahmadi et al. This is an open access article distributed under the Creative Commons Attribution License, which permits unrestricted use, distribution, and reproduction in any medium, provided the original work is properly cited.

Dye sensitized solar cells (DSSCs) have attracted numerous research, especially in the context of enhancing their efficiency and durability, due to the low-cost and environmentally friendly nature of photovoltaic (PV) technology. The materials in DSSCs are vital towards the realization of these goals, since many of the important components are influenced by their respective preparation and deposition methods. This review aims to detail the research and development aspects of the different physical methods with the purpose of evaluating their prospects and corresponding limitations. The diversity of consideration and criteria includes thin film applications, material characteristics, and process technology that need to be taken into account when selecting a specific deposition method. Choosing a deposition method is not as simple as it seems and is rendered quite complicated due to various factors. Usually, a researcher will evaluate techniques based on factors such as the different preparations and deposition technology with materials' and substrates' type, specified applications, costs, and efficiencies.

\section{Introduction}

Dye sensitized solar cells (DSSCs) in the form of novel photovoltaic (PV) technology have widely huge potential for low-cost and environmentally friendly solar cells compared to their more traditional counterparts. DSSCs are favored, due to properties such as low weight, flexibility, transparency, varied colors, and superior performance in darker conditions, and have attracted considerable private sector investment and government funding. DSSC is considered as a promising research topic, due to the dependence of its power conversion efficiency on its materials. However, the materials [1] alone are not enough to guarantee a stable, efficient, and lowcost dye sensitized solar cell [2-4], as its properties are intertwined with the preparation and deposition method. It has been prepared via various deposition technologies, and these technologies are being intensely researched and developed, due to their unique advantages over others. The purpose of this review highlights the different preparations and deposition methods that have been utilized in DSSC applications in order to emphasize their advantages and disadvantages, which will allow a researcher to select and optimize a given method. Moreover, other parameters such as sensitization and curing procedure play a significant role in DSSC's performance, which must be taken into account as well $[5,6]$. There are two major categories in the preparation and deposition methods, including chemical and physical methods. We analyzed the chemical methods in our previous paper [7], and this review will attempt to discuss the physical applied methods in the preparation of DSSC. Meanwhile, the combination of both physical and chemical reactions is being considered in the preparation of DSSCs; however, this review is limited to physical preparations. 


\section{Physical Methods}

Physical methods utilize physical phenomenon to prepare and deposit the materials. Physical methods are further categorized according to their medium or precursors, such as gas or liquid. We tried to categorize these methods by considering this concept, although it does overlap from time to time.

\subsection{Liquid Phase Precursors}

2.1.1. Spin Coating. Uniform thin films on flat substrates are deposited via the spin coating method, which encompasses products such as thin and ultrathin polymer films. Procedures on spin coating include deposition, spinup, spinoff, and evaporation (Figure 1). The overloaded solution is deposited onto the substrate, rotated at high speeds, and finally, the solution coats the substrate via centrifugal force. The desired thickness is obtained by continuous rotation. The solvent, being volatile, simultaneously evaporates. The film's thickness is dependent on the solution's concentration, solvent, and spin speeds [8]. The thin film is deposited by the high angular spin speed. The thickness of the films is less than $10 \mathrm{~nm}$, which is useful in microfabrication and photolithography, which requires the thickness of the photoresist to be circa 1 micrometer. The film thickness is explained as follows [9]:

$$
h=\left(1-\frac{\rho_{A}}{\rho_{A 0}}\right) \cdot\left(\frac{3 \eta \cdot m}{2 \rho_{A 0} \omega^{2}}\right)^{(1 / 3)}
$$

where $h$ is thickness, $\rho_{A}$ is density of volatile liquid, $\eta$ is solution viscosity, $m$ is evaporation rate, and $\omega$ is angular speed. For the experimental results, $h=A \omega^{-B}$ can be used, where $A$ and $B$ are constant parameters and $B=0.4$ and 0.7 in most cases. The desired thickness, uniform film, simple setup, and low power consumption are some of the advantages of this method. However, its dependence of the substrate's size of the spin coating process, the lack of material sufficiency, high cost, and its requirement for a flat substrate are some of its known disadvantages [10]. As can be seen in Table 1, the list of materials could be used via the spin coating method in DSSC application.

2.1.2. Dip Coating. Dip coating results in a uniform thin film of liquid deposition upon the substrate for small slabs and cylinders (Figure 2). The thickness of the film depends on the viscous force, capillary (surface tension) force, and gravity. The flow conditions of the liquid bath and gas overhead play an important role in both thicknesses and uniformities. Thicker films resulted from using volatile solutes and combining rapid sufficient drying via basic liquid flow. The growth, theoretical prediction, and control of the process represent some of the challenges faced when utilizing this method. If the withdrawal speed is chosen in a way that the sheer rates remain with the Newtonian regime, the thickness deposition

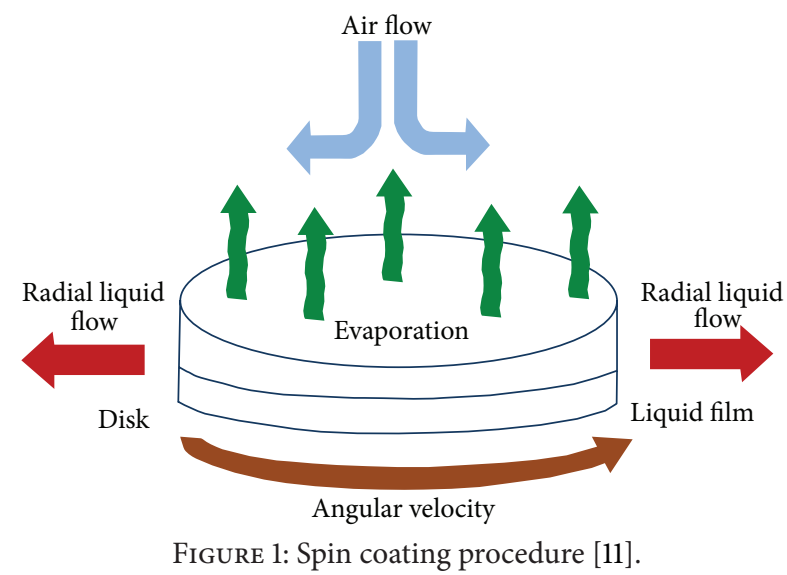

can be calculated by the Landau-Levich equation, as follows [14]:

$$
h=0.94 \cdot \frac{(\eta \cdot v)^{2 / 3}}{\gamma_{\mathrm{LV}}^{1 / 6}(\rho \cdot g)^{1 / 2}}
$$

where $h$ is coating thickness, $\eta$ is viscosity, $v$ is dragging speed, $\gamma_{\mathrm{LV}}$ is liquid-vapor surface tension, $\rho$ is density, and $g$ is the gravity constant.

The dip coating process is divided into five steps [15]. (1) Immersion: the substrate is immersed in the coating material solution at a consistent speed for a moment, and (2) startup: the substrate is subsequently pulled up, which precipitates the formation of a thin layer to form on the substrate. Pullingup is performed at a steady speed to eliminate any potential jitters. (3) Deposition: the thickness of the coating is controlled by the pull speed, as a thicker coating will form if the pull (withdrawal) speed is increased. If a thinner layer is required, then (4) drainage: the excess liquid is drained, and (5) evaporation: any remaining solution on the coating is evaporated using volatile solvents such as alcohols. This step is continuously repeated. The dip coating method is rather common, while the spin coating method that was previously discussed is more suitable for industrial purposes [16]. The dip coating method is used in DSSC applications, such as Poly $(N$-vinyl2-pyrrolidone)-capped platinum nanoclusters deposited on indium tin oxide glass (efficiency, 2.84\%) [17] and mesoporous $\mathrm{TiO}_{2}$ films deposited on an F-doped tin oxide with dye (ruthenium complex bis-tetrabutylammoniumcis-dithiocyanato- $N, N^{\prime}$-bis- $2,2^{\prime}$-bipyridine- 4 -carboxylic acid, $4^{\prime}$-carboxylate ruthenium(II)) (efficiency, 10.80\%) [18].

2.1.3. Doctor Blade Printing (Knife to Edge) Roll to Roll. Ceramic capacitors are the first recorded tape-casting machines that were made by Glen Howatt [19], and this marvelous invention is soon followed by the doctor blade or tape casting method. The multilayer ceramic capacitors (MLCCs), low temperature cofired ceramics (LTCCs), lithium batteries, fuel cells, oxygen separators, and thermistors are some of the devices that are manufactured by the tape casting method. The application of this method vis-à-vis thin films is relatively recent, which found its niche in nanotechnological advances 
TABLE 1: List of materials was prepared via spin coating method for fabrication DSSC using some research results.

\begin{tabular}{|c|c|c|}
\hline Materials & $\begin{array}{c}\text { Efficiency } \\
\eta(\%)\end{array}$ & Reference \\
\hline Poly-3-phenylhydrazone thiophene (PPHT):ZnO/PPHT:Dye:ZnO & 0.55 & {$[64]$} \\
\hline PEDOT:PSS film on FTO glass substrate & 6.37 & {$[65]$} \\
\hline $\mathrm{ZnO}$ nanowires & 5.20 & {$[66]$} \\
\hline Pt electrodes & 7.18 & {$[67]$} \\
\hline 7,14-Bis[2-[tris(1-methylethyl)silyl]ethynyl]dibenzo[b,def] chrysene (TIPS-DBC) layers on SWNT/FTO & - & {$[68]$} \\
\hline MWCNT on FTO & 4.94 & [69] \\
\hline $\mathrm{TiO}_{2}$ nanoparticles/nanofibers bilayer film & 4.75 & {$[70]$} \\
\hline Nanocarbon composite with hierarchical porous structure & 6.50 & {$[71]$} \\
\hline Camphorsulfonic acid doped polyaniline (PANI/CSA) film & 2.67 & {$[72]$} \\
\hline Mesoporous $\mathrm{TiO}_{2}$ & 6.92 & [73] \\
\hline $\mathrm{Al}_{2} \mathrm{O}_{3}$ and $\mathrm{SiO}_{2}$ nanoparticles on $\mathrm{ZnO}$ nanowire and nanoparticles & 2.40 & {$[74,75]$} \\
\hline PEDOT:PSS (transparent thin films) & - & {$[76]$} \\
\hline $\mathrm{TiO}_{2} / \mathrm{NiO}$ composite particles & 3.27 & [77] \\
\hline Thin film of $\mathrm{ZnO}$ on FTO (2Ml) & 6.70 & {$[78]$} \\
\hline $\mathrm{ZnO}$ compact film & 7.76 & {$[79]$} \\
\hline $\mathrm{TiO}_{2}$ film & - & {$[80]$} \\
\hline A polystyrene (PS) film of microporous or island-like structure & 4.58 & {$[81]$} \\
\hline Graphene/PEDOT-PSS & 4.50 & {$[82]$} \\
\hline Thin films of poly(3,4-ethylenedioxythiophene)-poly(styrenesulfonate) (PEDOT:PSS) & 0.34 & {$[83]$} \\
\hline Carbon-modified $\mathrm{TiO}_{2}$ electrode & 5.60 & {$[84]$} \\
\hline $\mathrm{TiO}_{2} / \mathrm{PEDOT}$ & 0.93 & {$[85]$} \\
\hline $\mathrm{SnO}_{2}$ colloidal suspension $(18 \mathrm{~nm})$ & - & {$[86]$} \\
\hline Oleic acid graphite (OLA-G) films on FTO glass & 0.77 & [87] \\
\hline Spiro-OMeTAD (2,2',7,7' -tetrakis-(N,N-di-p-methoxyphenylamine)-9,9' -spirobifluorene) & 3.02 & {$[88]$} \\
\hline
\end{tabular}

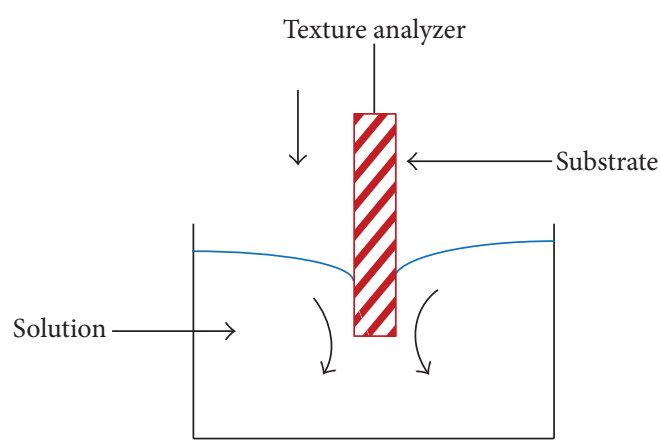

(a)

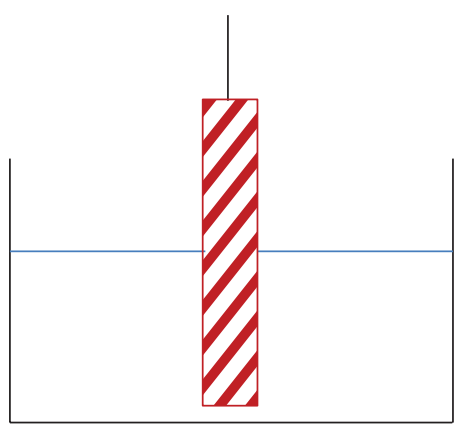

(b)

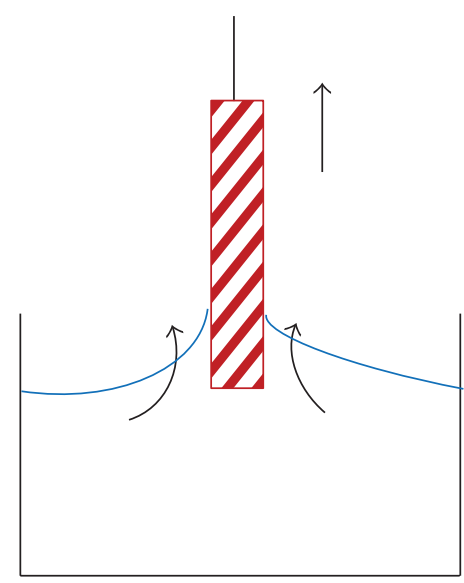

(c)

FIGURE 2: Scheme of dip coating process: (a) immersion, (b) wetting, and (c) withdrawal [12]. 

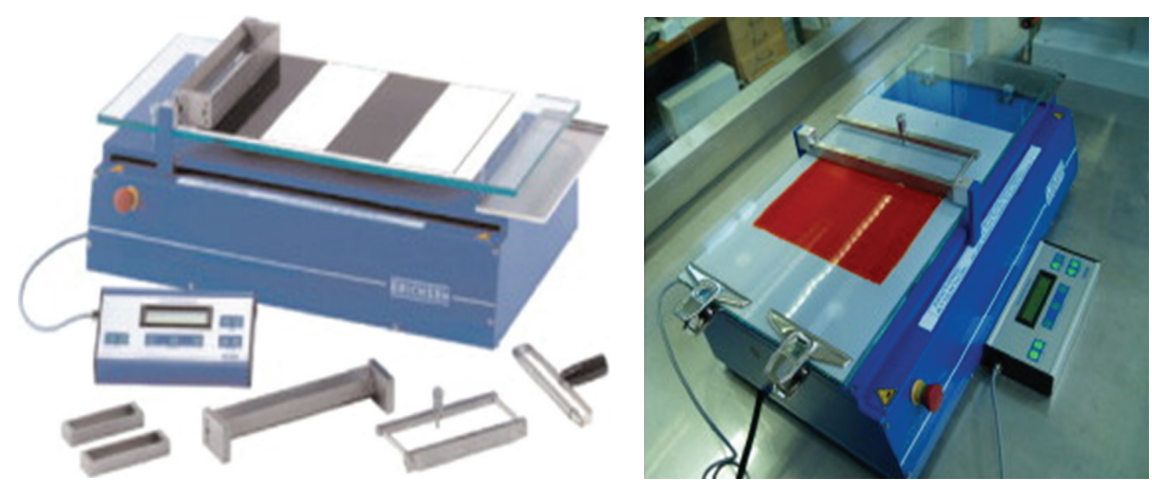

(a)

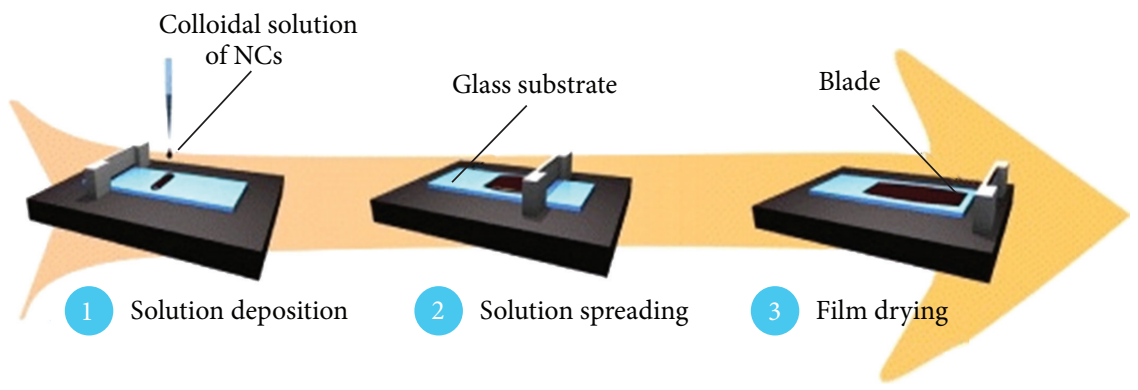

(b)

Figure 3: (a) A photograph of doctor blading (ErichsenCoatmaster $509 \mathrm{MC}-\mathrm{I}$ ) [11] and (b) First step: the colloidal solution is deposited onto glass substrate; second step: the blade spreads the solution over the substrate; third step: the obtained film is dried [13].

in ceramic body armor, optical films, medical films used as drug delivery systems, and microporous membranes.

The well-defined thickness of films fabricated using the doctor blade technique is detailed in Figure 3. This method, aptly named tape casting, knife coating, or knife-over-edge coating, due to transfer to reel-to reel coating (R2R), is also viable to be used to make films for polymer solar cells [20]. The stages of this technique are summarized as the movement of a substrate at a constant speed under a blade, with a specific height and contact angle. The function of this blade is to spread the paste onto the surface homogeneously and get a fixed thick film. We can also conduct the process by placing a fixed amount of paste over the substrate to be deposited and then unrollis, using a glass rod, is moved on the spacer on both sides to determine the thickness of the film.

This method is economical, and it minimizes the loss of particles by around 5\% compared to its spin coating counterpart. As a result of this, only a small amount of starting materials is sufficient for this method [11]. The coated thickness is around $10-500 \mu \mathrm{m}$ using a sharp blade at a fixed distance from the substrate's surface. The wet thickness of the film depends on the surface tension and the viscosity of the coating solution. In practical terms, this technique is analogous to spin coating, due to the enhanced initial loss of coating solution, and the extended time that is required to determine the best coating parameters. However, it is considered as one of the most straightforward and low-cost process for semi-conductor paste deposition and one of the simplest printing methods available for modern electronics.
This method is suitable for mass production of electroceramic thick films, as it requires less starting materials compared to the spin coating method. Despite its benefits, there are some areas where it is lacking, such as its slow evaporation or its tendency to aggregate or crystallize at high solution/paste concentration. The large effective area of the photovoltaic devices is based upon the compatibility between the accepters and donors. For example, the best combination between fullerene as an acceptor and polymer (paraphenylenevinylene, PPV) as a donor material is viable for the doctor blade method without any loss of efficiency [21]. This process could be performed manually in the laboratory (Table 2). The researchers have built simple and quick samples of nanostructure semiconductor films, and this method also allows science hobbyist to construct homemade solar cells.

2.1.4. Screen Printing. The screen printing process is twodimensional print layer patterning devised in the 20th century, which was determined to have numerous industrial applications. First, the porous printing plate is fabricated using a woven mesh of synthetic fabric threads or metal wire, which is duly mixed with stencil as a masking material. The process is detailed in Figure 4. The woven mesh is attached to a rigid aluminum or steel framework, which has a rectangular plane in a majority of the applications. However, the cylinder screen is also considered to be attached and sealed at both ends. The semirigid planar surface creates tension in the opposite direction of the mesh, similar to 
TABLE 2: The summarized materials are used by doctor balding method for DSSC application.

\begin{tabular}{|c|c|c|}
\hline Materials & $\begin{array}{c}\text { Efficiency } \\
\eta(\%)\end{array}$ & Reference \\
\hline Blends of polymer and fullerene & - & [21] \\
\hline $\begin{array}{l}\text { Porous carbon } / \mathrm{SnO}_{2} / \mathrm{TiO}_{2} \\
\text { nanocomposite films }\end{array}$ & 6.15 & [89] \\
\hline Sn doped $\mathrm{ZnO}$ nanostructures & 1.82 & [90] \\
\hline ZnO photoelectrodes & 1.07 & {$[91]$} \\
\hline ITO-PEN & 4.24 & [92] \\
\hline $\mathrm{ZnO}$ porous film & 4.64 & {$[93]$} \\
\hline $\mathrm{TiO}_{2}$ layer & 8.10 & {$[94]$} \\
\hline Carbon counter electrode (CE) & 6.46 & {$[95]$} \\
\hline Porous carbon counter electrodes & 6.10 & [96] \\
\hline $\begin{array}{l}\mathrm{TiO}_{2} \text { film was coated on a } \\
\text { Ti-isopropoxide-treated } \\
\text { stainless steel-based substrate }\end{array}$ & 8.30 & [97] \\
\hline Cauliflower-like $\mathrm{TiO}_{2}$ rough spheres & 7.36 & {$[98]$} \\
\hline Porous $\mathrm{ZnO}$ photoelectrode & 4.50 & {$[99]$} \\
\hline Mesoporous $\mathrm{TiO}_{2}$ film & 5.80 & {$[100]$} \\
\hline FTO glass & 9.10 & {$[25]$} \\
\hline $\mathrm{ZnO}$ and $\mathrm{TiO}_{2}$ & 1.60 & {$[101]$} \\
\hline Mesoporous $\mathrm{TiO}_{2}$ electrodes & 0.50 & {$[102]$} \\
\hline Pure anatase $\mathrm{TiO}_{2}$ nanocrystallites & 5.65 & {$[103]$} \\
\hline $\mathrm{TiO}_{2}$ porous film & $\begin{array}{c}3.10 \text { (glass } \\
\text { substrate) } \\
4.90 \text { (plastic } \\
\text { substrate) }\end{array}$ & [104] \\
\hline $\mathrm{TiO}_{2}$ on FTO glass & 5.18 & {$[105]$} \\
\hline $\mathrm{TiO}_{2}$ photoanodes FTO glass & $\begin{array}{l}7.21 \text { (front side) } \\
4.85 \text { (back side) }\end{array}$ & [106] \\
\hline
\end{tabular}

the tensions generated via the interaction between synthetic polyester monofilaments or stainless steel. This stretched printing screen achieves three discrete purposes: (1) the fluid coating meters under pressure, (2) providing a surface for the shearing of the coating material viscous columns to transfer to the substrate, and (3) providing support for the imaging elements (the stencil). This method eliminates any loss of the coating solution and produces a large wet thick film with a high viscosity.

The screen printing method uses thick film printing, producing films that are around 10-15 microns. Example of application of this method includes the DSSC electrode, with $\mathrm{TiO}_{2}$ as thick film deposited on a conductive glass (FTO/ITO). This method is widespread in the electronic industries to manufacturing DSSC in producing miniature and robust electronic circuits in a cost-effective manner, massive and automated, well-defined, and with highly reproducible structures. First, the thick film screen printing ink or paste is pressed onto the substrate by a mechanical squeegee, transferring the patterns [22]. This method consists of a solvent (organic or inorganic salt) and a binder $\left(\mathrm{TiO}_{2}\right.$ particles). The role of the solvent provides an ink homogeneous mixture for printing purposes. The screen includes woven mesh of stainless steel, nylon, or polyester mounted under tension on a metal frame. During printing, the substrate is held at a distance from one side of the screen and the ink is deposited on the screen from the opposite side, while a squeegee traverses the screen under pressure. Second, the solvent will be dried at $120^{\circ} \mathrm{C}$, which automatically guarantees the stability of the printed films and substrates. The nonvolatile portion of the solvent evaporates under high temperature. The most popular screen printable ink recipe contains ethanol for its solvent, terpineol for its dispersant, ethyl cellulose for its thickener, and Triton X-100 for its surfactant [23]. The water solvent causes cracks to form on the film, so organic solvents are used. The long stability and superior morphology of $\mathrm{TiO}_{2}$ are important in dye adsorption, which utilize terpineol component and ethyl cellulose, respectively. The loading nanoparticles on screening print are important, because they affect the $\mathrm{TiO}_{2}$ structure, although they reduce the efficiency of DSSC if the dispersion is incomplete. The low current output and the decline in the efficiency of the solar cell are due to the agglomeration of nanoparticles. The thickness of the coated film is superior compared to the other methods, such as offset lithography, gravure, flexography, xerography, or ink-jet printing, caused by the flow of coating material being under pressure into and through this mesh or matrix via coating on the substrate. The high efficiency for DSSC is around $9.1 \%$ for porous $\mathrm{TiO}_{2}$ [24] and carbon black [25]. The $\mathrm{ZnO}$ nanoparticle shows an efficiency of $1.50 \%$ [26], whereas $\mathrm{ZnO}$ nanoparticles with two indoline dyes, coded D149 and D205, observe higher efficiencies at 4.95\% (D149) and 5.34\% (D205), respectively [27]. The ITO-PEN [28] and Pt deposited on ITO/polyethylene naphthalate (ITO/PEN) [29] have efficiencies of $5.41 \%$ and $7.20 \%$, respectively.

\subsubsection{Electrohydrodynamic Deposition (Electrospray Deposi-} tion; ESD). The liquid-phase process is a new method for fabricating thin films that are thinner than $10 \mu \mathrm{m}$ in MEMS (Microelectromechanical Systems) and NEMS (Nanoelectromechanical Systems) (Figure 5). The electrospray forms droplets from the sample solution, such as nanoparticles, and these droplets will be deposited on various substrates. The uniform solid film is formed by evaporating or heating the solvent on the surface via sintering. The thin films could be formed by a precursor compound, which decomposes at high temperatures or converts to another substance via chemical reactions with other compounds that are simultaneously sprayed or delivered during its gaseous phase [30]. This method could be used in physical and chemical reactions that are taken into account in the physical aspect in this review. The metal nitrates or acetates dissolve in water, methanol, and ethanol, and these mixtures are electrosprayed as precursors for a metal-oxide layer production. The advantage of this method is the usage of the less soluble materials [31], the ability to control charge droplet, the lack of solvent evaporation effects, and the ability to form multilayered thin films. The significant advantage of ESD is the multilayered thin film growth being superior compared to spin coating, dip coating, and screen printing, since the bottom organic layer solvent during the top layer growth cannot be avoided 


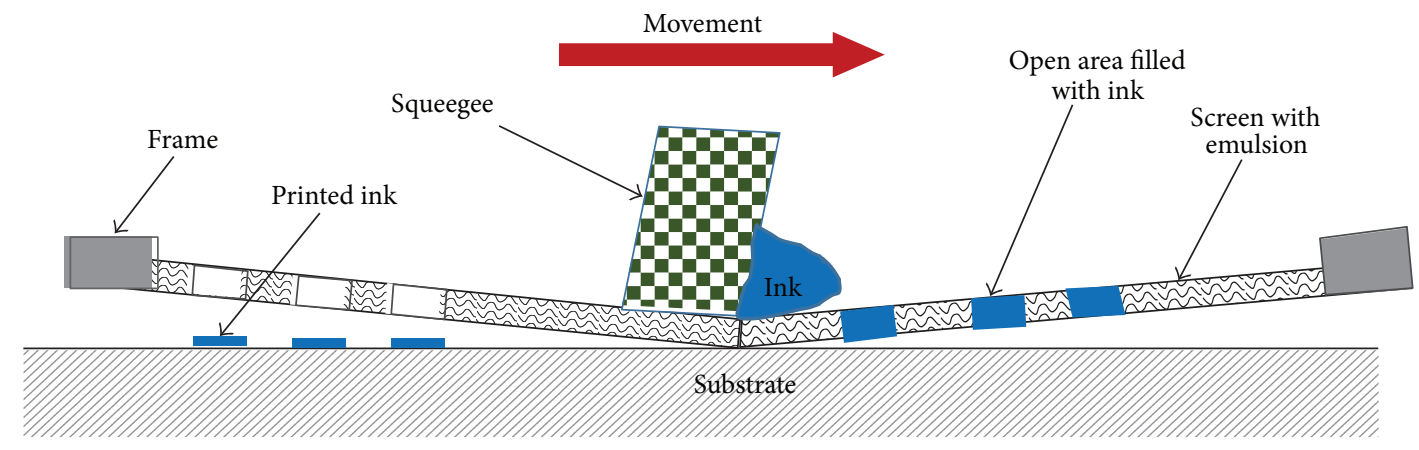

FIGURE 4: Schematic of screen printing [11].

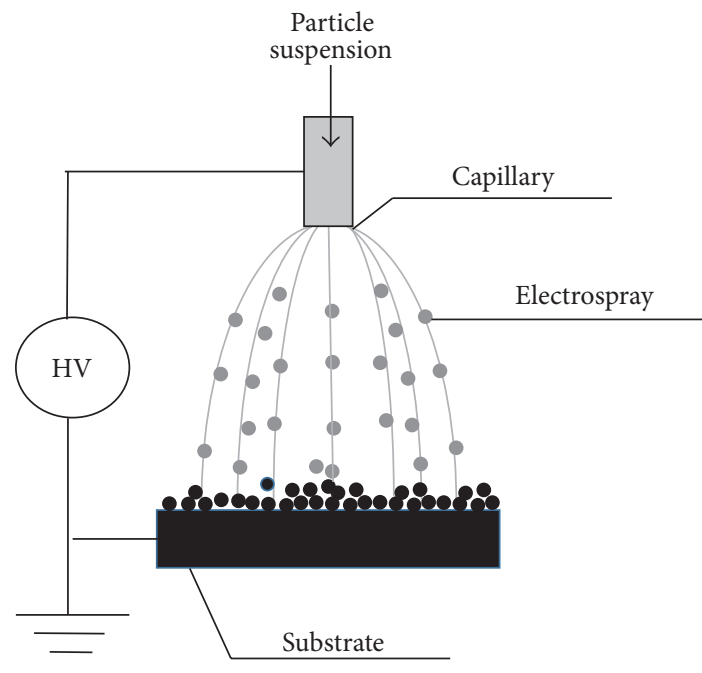

(a)

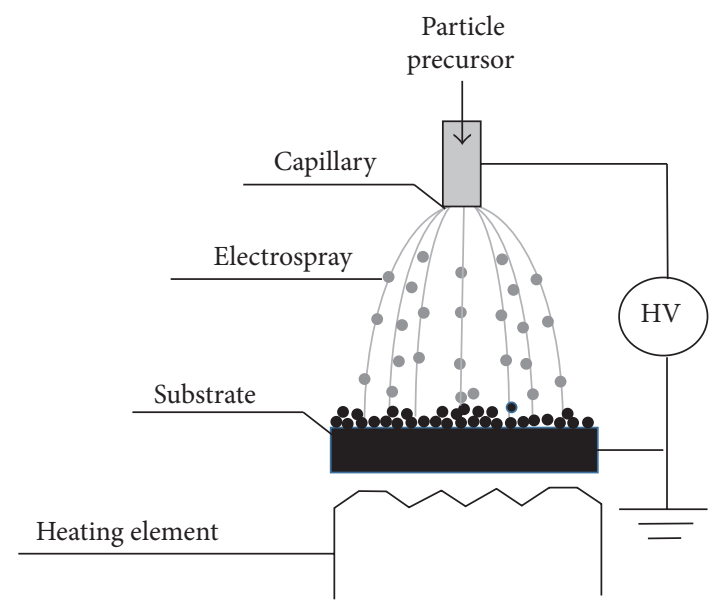

(b)

FIGURE 5: Schematic of electrospray deposition (a) from solution and (b) from precursor [30].

[32]. The nanocrystalline $\mathrm{TiO}_{2}$ electrodes [33], porous $\mathrm{TiO}_{2}$ films [34], and terpyridine-coordinated dye [33] had the efficiencies of $5.97 \%, 5.10 \%$, and $2.48 \%$, respectively. The spray dye molecules onto $\mathrm{TiO}_{2}$ surfaces used this method to develop molecular dye sensitized solar cells [31]. High conductivity (electrical resistivity of $2 \times 10^{-4} \Omega \mathrm{cm}$ ) and high transmission of $78 \%$ in the visible range were observed in Tin oxide films [35].

\section{Gas Phase Precursors}

3.1. Physical Vapor Deposition (PVD). Thin film deposition via $\mathrm{PVD}$ is regarded as a vacuum coating technology and is classified into two techniques, evaporation and sputtering. The material could be coated in an energetic and entropic environment, since the particles will escape from the surface. The solid layer that is formed on the surface is due to the cooling of the particles once they lose their energy when immobilized. The particles are capable of moving in a straight path because the system is kept in vacuum, and the films are coated by physical means that are commonly directional, rather than conformal, in nature. Examples of PVD method prepared nanostructures in DSSCs are mesoporous $\mathrm{TiO}_{2}$ nanocolumnar films [36] (3 mm-linear: efficiency (2.40\%), $3 \mathrm{~mm}-500 \mathrm{~nm}$ : efficiency $(2.20 \%), 3 \mathrm{~mm}-100 \mathrm{~nm}$ : efficiency (2.30\%), $5 \mathrm{~mm}-500 \mathrm{~nm}$ : efficiency $(2.50 \%)$, and $6 \mu \mathrm{m}$ reference P25 electrode: efficiency (2.10\%)), $\mathrm{ZnO}$ nanostructures deposited on glass ITO substrate (efficiencies $(0.10 \%-0.50 \%)$ for nanowires, nanowire sheets, branched $\mathrm{Au}$, and branched $\mathrm{Zn}$ [37]), $\mathrm{TiO}_{2}$ (nanotubes) deposition enhance dye loading to up to $47.20 \%$ and changing the efficiency to $6.28 \%$ for DSSC [38], and $\mathrm{TiO}_{2}$ electrodes deposited at different angles $(500 \mathrm{~nm}$ thickness: efficiency $(0.60 \%-1.04 \%)$ with modified angle $\left(60^{\circ}-85^{\circ}\right)$ and $3 \mu \mathrm{m}$ thickness: efficiency (2.78\%) [39]).

3.1.1. Evaporation. Generally, thin films are deposited by evaporation. The source material is evaporated in a vacuum, which allows the vapor particles to travel directly to the substrate as a target and condense into a solid state.

Thermal Evaporation. Thermal evaporation is a simple and economical method in fabricating thick films and microfilms (Figure 6). The source materials are melted or sublimated via electrical heating, converting it into a gaseous phase. 
TABLE 3: Thermal evaporation method used for DSSC application.

\begin{tabular}{lcc}
\hline Materials & $\begin{array}{c}\text { Efficiency } \\
\eta(\%)\end{array}$ & Reference \\
\hline ZnO nanocombs onto FTO substrate & 0.68 & {$[107]$} \\
ZnO:Sb fiber on FTO & - & {$[108]$} \\
ZnO with different thickness of NiO thin & $1-0.9$ & {$[109]$} \\
films & $0.34-0.85$ & {$[110]$} \\
Arrays of $\mathrm{ZnO}$ nanowires & - & {$[111]$} \\
Mesoporous $\mathrm{TiO}_{2}$ & 1.56 & {$[112]$} \\
ZnO films onto FTO & 0.88 & {$[113]$} \\
ZnO nanofibers & 2.70 & {$[114]$} \\
Ag nanowires & 2.70 & {$[115]$} \\
Pt thin film on FTO & &
\end{tabular}

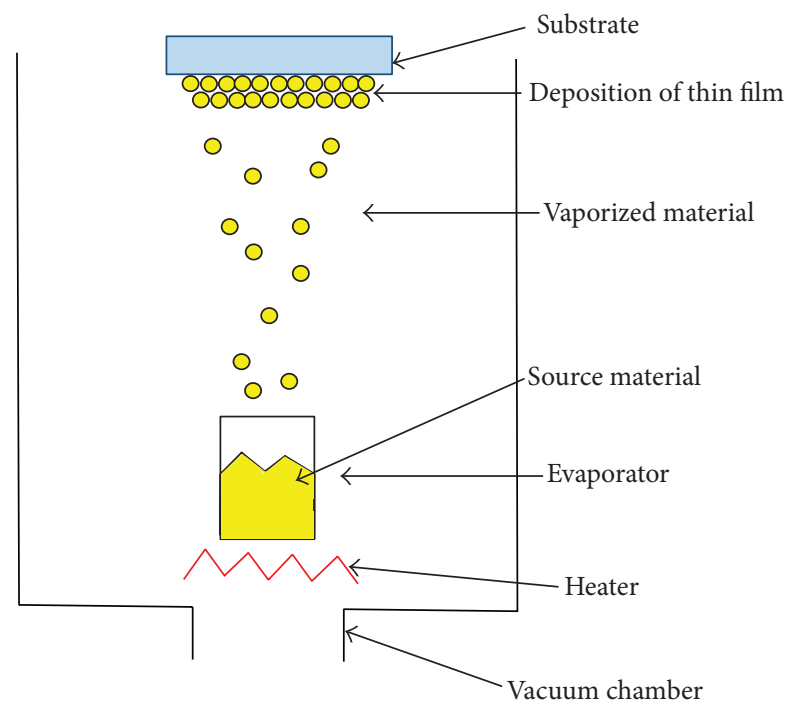

Figure 6: Schematic of thermal evaporation [40].

The vapor particles will then achieve a certain velocity in the chamber and will attempt to condense on the substrate. The substrates are located close to the source materials. The high vacuum condition in the vacuum chamber will act to prevent the particles from scattering and minimize the residual gas impurities. The temperature is kept between $1000 \sim 2000^{\circ} \mathrm{C}$. There are some disadvantages, including poor adhesion because of low affinity with substrate surface and the need to use an adhesive layer due to evaporated temperature, metal and low melting point materials are suitable and refractory materials and multicomponent alloys cannot be used, contamination problems, and poor step coverage (rendering pattern making impossible). The film coated without contamination is made by materials that have a much higher vapor pressure than the heating element. The temperature and vapor pressure affect high deposition rates (up to $100 \mu \mathrm{m} / \mathrm{min}$ ). Surface damage is low because the vapor particle energy is

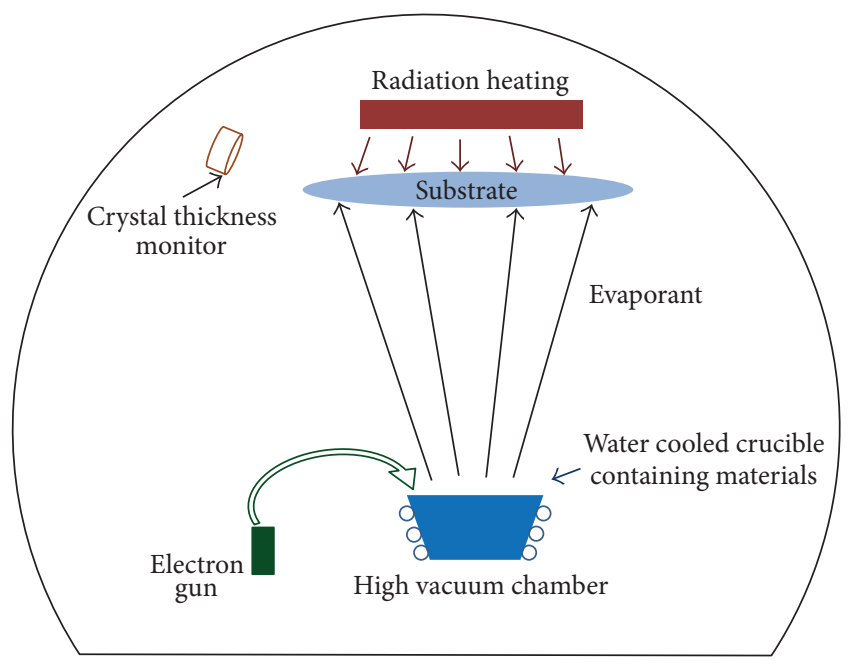

FIGURE 7: Schematic of electron-beam evaporation process [41].

around 10 100 meV. The applications of DSSC are listed in Table 3.

Electron Beam Evaporation (EBE). Electron beam evaporation used high-speed electrons to bombard the source materials. During this process (Figure 7), the kinetic energy will be converted into thermal energy, which increases the temperature of the source. An electron gun creates the electron beam. The magnetic field bends at an angle of $270^{\circ}$, and the electron path bombards the position. The crucible acts as an anode and is cooled by cooling water to prevent contamination. Consequently, a pure thin film is formed. Quite a number of materials could be formed using this method, such as dielectric oxide, refractory metals, and metal oxide (Table 3 ). This method allows the easy control of the melting materials, which makes its deposition rate easily controlled as well $(1 \mathrm{~nm} / \mathrm{min}$ to $1 \mu \mathrm{m} / \mathrm{min})$ using multiple guns and sources. These advantages enhance the uniform thickness and create a multilayer deposition by changing the crucible and making multiple target film possible. The surface, however, could easily be damaged by the decomposition or ionization of the target. However, the enormous electrical energy and Xray that is consumed in this method put it at a distinct disadvantage. The EBE used in DSSC application is shown in Table 4.

3.1.2. Sputtering. The sputtering method was discovered in 1852 as a means to monitor metals deposit at the cathodes of a cold cathode glow discharge. This method was used to coat mirror fabrics and phonograph wax masters. We analyzed two kinds of sputtering, including DC magnetron sputtering and radio frequency (RF) magnetron sputtering. DC magnetron sputtering could increase deposition rates with minimal damage to the substrate, while the RF magnetron sputtering plays an important role in allowing direct deposition of insulators. The high quality deposition materials such as metal, alloy, and simple organic compound coatings were deposited using the sputtering method, which 
TABLE 4: List of materials by using EBE method in DSSC application.

\begin{tabular}{|c|c|c|}
\hline Materials & $\begin{array}{c}\text { Efficiency } \\
\eta(\%)\end{array}$ & Reference \\
\hline Ti electrode coated on $\mathrm{TiO}_{2}$ layer & 2.51 & [116] \\
\hline $\mathrm{TiO}_{2}$ films & 4.00 & [117] \\
\hline $\begin{array}{l}\mathrm{TiO}_{2} \text { between the conductive transparent } \\
\text { electrode and the porous } \mathrm{TiO}_{2} \text {-based } \\
\text { photoelectrode }\end{array}$ & 7.01 & [118] \\
\hline $\begin{array}{l}\text { Composite electrolyte (mixture of } \\
\text { heteropoly acids (HPA) and polyethylene } \\
\text { oxide (PEO)) }\end{array}$ & 3.40 & [119] \\
\hline $\mathrm{TiO}_{2}$ film & 6.64 & [120] \\
\hline Porous films of titanium oxide & 4.10 & {$[121]$} \\
\hline Nanoporous films $\left(\mathrm{TiO}_{2}-6 \mu \mathrm{m}\right)$ & 6.10 & {$[122]$} \\
\hline $\begin{array}{l}\text { Nanocolumnar titanium oxide films } \\
(4 \mu \mathrm{m})\end{array}$ & - & {$[123]$} \\
\hline
\end{tabular}

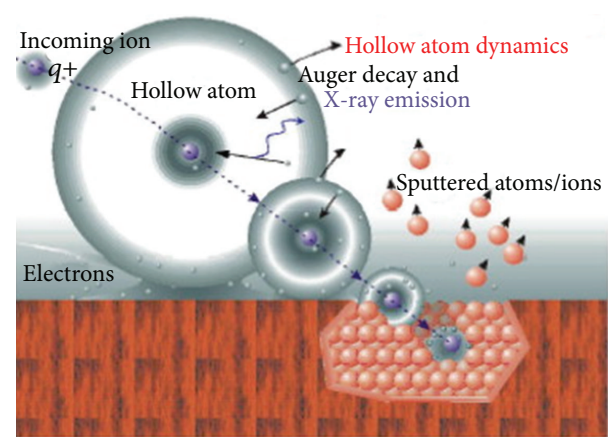

FIGURE 8: Schematic of the processes that follow ion impact during sputtering [42].

precipitates the preference of this method over other PVD methods such as EBE and thermal evaporation (Table 5). Sputtering is considered a momentum transfer procedure. As the particles collide with a surface, the procedure is dependent upon the incident particle energy, the incidence angle, the surface atoms binding energy, and the colliding particles mass (Figure 8). The ions are regarded as the incident particles in sputtering, which are accelerated by an applied electrical potential. They will be reflected or absorbed by the surface when the kinetic energy is less than $5 \mathrm{eV}$. The surface will be damaged as the kinetic energy is higher than the surface atom binding energy when the atoms are placed into new lattice positions.

Sputtering occurs from the surface when the kinetic energy is above a certain threshold $(10$ to $30 \mathrm{eV})$. The sputtered atoms and ions deposit the thin film onto the substrate. A low-pressure process of the glow discharge type will usually cause energetic ion bombardment. The basic diode process is revealed in Figure 9. The vacuum chamber (argon, $10-3$ to $10-1$ torr) is supplied with a cathode as its target, the coating material source, and an anode as substrate for coating. During the sputtering process, the heat generated in the target is connected to a water-cooled metal (copper) backing plate with a solder or conductive epoxy, which cools the target. An electrical potential is applied between the cathode and anode. Grounded shields avoid discharges from forming in

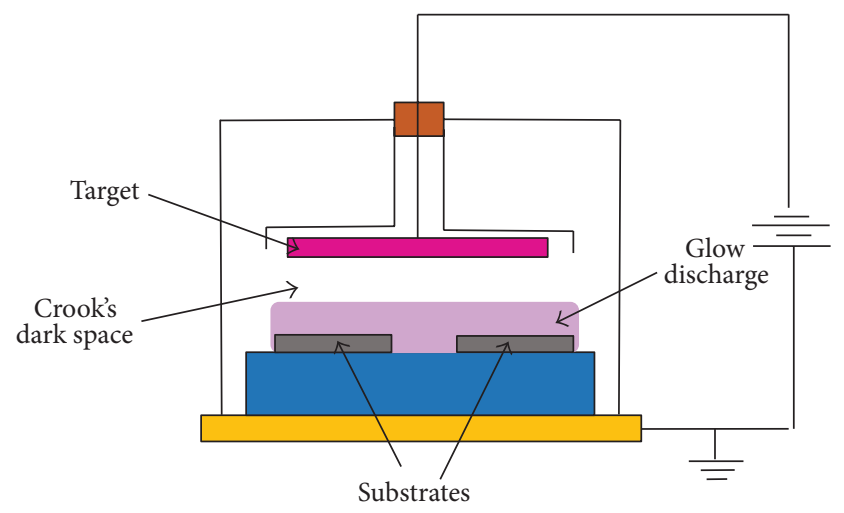

FIGURE 9: Schematic of a diode sputtering assembly [43].

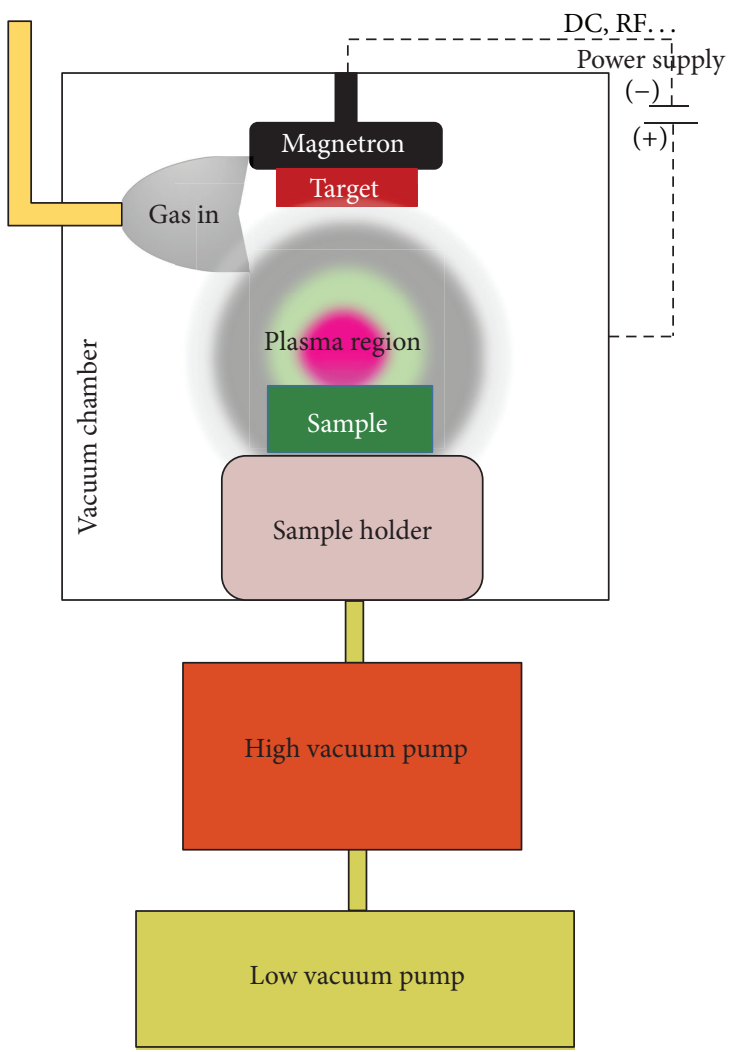

FIGURE 10: Graphic of DC and RF sputtering [44].

undesirable areas. The sputter yield is dependent on the target material; for example, silver has high yield. The deposition of large amounts of materials, including compounds and mixtures, the inducement of better step coverage and uniformity, and good adhesion with low substrate temperature are some of the advantages of this process, but the risk of substrate damage due to ionic bombardment is omnipresent. The list of materials used in DSSC application is shown in Table 4.

DC Magnetron Sputtering. DC magnetron sputtering is one of the simpler and older sputter depositions methods. It is made up of two parallel electrodes $4-8 \mathrm{~cm}$ apart, a cathode (target), and an anode (substrate) (Figure 10). The typical DC 
TABLE 5: DSSC application by using sputtering method.

\begin{tabular}{|c|c|c|}
\hline Materials & $\begin{array}{c}\text { Efficiency } \\
\eta(\%)\end{array}$ & Reference \\
\hline ITO-PEN & 8.10 & {$[94]$} \\
\hline $\mathrm{TiO}_{2}$ nanowires/nanoparticles hybrid membrane & $2.50-2.70$ & {$[124]$} \\
\hline $\mathrm{ZnO}$ nanostructured films & $>4.58$ & {$[125]$} \\
\hline Nanofibrous $\mathrm{ZnO}$ layers & 1.70 & [126] \\
\hline $\mathrm{ZnO}$ compact layer & 7.81 & [127] \\
\hline Pt counter electrodes on micropatterned ITO substrates & 5.36 & [128] \\
\hline $\mathrm{TiO}_{2}$ blocking-layer coated CdS-sensitized & 0.52 & {$[129]$} \\
\hline PAMAM-like dendrons on SWCNT & - & [130] \\
\hline $\mathrm{TiO}_{2}$ microspheres with tunable sizes & 6.78 & {$[131]$} \\
\hline Pt-counter electrode (Pt-CE) & 7.54 & [132] \\
\hline Pt layer & 5.11 & [133] \\
\hline Carbon films & 5.00 & [134] \\
\hline Thin Pt electrode on transparent conductive oxide (TCO) substrate & 6.00 & [135] \\
\hline Composite poly(3,3-diethyl-3,4-dihydro-2H-thieno-[3,4-b][1,4]-dioxepine) and platinum (PProDOT-Et $\left.{ }_{2} / \mathrm{Pt}\right)$ film & 6.68 & [136] \\
\hline Ultra-thin Pt films on indium tin oxide (ITO) substrates & 7.90 & [137] \\
\hline ITO-x-SWCNT and ITO-x-SWCNT-N3 electrodes & - & [138] \\
\hline $\mathrm{TiO}_{2}$ nanoparticles with natural dye extracted from pomegranate leaves and mulberry fruits & $0.55-0.72$ & [139] \\
\hline ZnO films of polyethylene glycol (PEG) & 1.83 & [140] \\
\hline Pt/Ti bilayers & 4.37 & {$[141]$} \\
\hline CdS-sensitized $\mathrm{TiO}_{2}$ photoelectrode & 1.04 & [142] \\
\hline Different $\mathrm{TiO}_{2}$ passivating layers & 2.85 & [143] \\
\hline $\mathrm{ZnO}$ nanorod & 0.32 & {$[144]$} \\
\hline Ti doped ITiO films & 3.80 & {$[145]$} \\
\hline $\mathrm{FTO} /$ nano- $\mathrm{TiO}_{2}$ & 4.40 & [146] \\
\hline FTO glass & 11.18 & [147] \\
\hline ITO-PEN film coated Pt layer & 5.24 & {$[148]$} \\
\hline Carbon electrode & 3.89 & [149] \\
\hline Polymerized poly(3,4-ethylenedioxythiophene) on conductive glass & 4.50 & {$[150]$} \\
\hline
\end{tabular}

potential that is applied is $1000-3000 \mathrm{~V}$, the vacuum pump is $10^{-3} \mathrm{~Pa}$, and pressures are about 0.075 to 0.12 torr. Ions will be accelerated in the plasma to the cathode, then the target will be bombarded, and the sputtering energy is transferred from the target to the substrate's surface. This method should be used for conductive materials and is unsuitable for dielectric material targets (Table 6). The good adhesion, very low levels of contamination, film properties control of pressure, bias, and temperature are some of the advantages of DC sputtering, whereas some of its significant disadvantages include plasma electrons bombarding the substrate and producing heat, high working gas pressure, low deposition rate, and targets being limited to electrical conductors. The performance of this system can be improved by cathode systems.

Radio Frequency (RF) Magnetron Sputtering. Insulating materials are suitable as materials in RF sputtering, which are induced by a positive charge on the target surface (Table 7). The negative bias voltage is produced on the target when the AC potential with high frequency is applied, mostly due to the mobility difference between electrons and ions. The positive ions bombard the target, leading to sputtering (Figure 10). The deposition rate of RF sputtering mirrors DC sputtering, where the target will be positive for a short time when the mass electron approaches the mass of ions. Therefore, the negative bias instigated sputtering on an insulating target. Practical applications utilized a frequency of around $13.56 \mathrm{MHz}$, and for industrial purposes, utilized a radio frequency designed by the Federal Communications Commission. RF sputtering deposits insulators with the same equipment and at lower pressures (5 to $15 \times 10^{-3}$ torr), as well as conductors and semiconductors. The blockage of the RF radiation by electromagnetic shielding is one of the major disadvantages of RF sputtering. Additionally, resonant RF network requires complex equipment such as the power supplies and matching networks. Overall, RF sputtering demonstrates lower deposition rates compared to DC sputtering, but its damage to a substrate is significantly lower than that of its DC counterpart. 
TABLE 6: The list of materials used via DC magnetron sputtering in DSSC application.

\begin{tabular}{lcc}
\hline Materials & $\begin{array}{c}\text { Efficiency } \\
\eta(\%)\end{array}$ & Reference \\
\hline $\mathrm{ZnO}$ film & 1.82 & {$[151]$} \\
$\mathrm{Pt}$ metal grid & 4.03 & {$[152]$} \\
Compact $\mathrm{TiO}_{2}$ deposited onto & 6.12 & {$[153]$} \\
fluorine-doped tin oxide (FTO) & 1.96 & {$[154]$} \\
$\mathrm{Pt} / \mathrm{TiN}$ thin film on PEN substrate & 4.38 & {$[155]$} \\
$\mathrm{TiO}_{2}$ nanotube arrays & - & {$[156]$} \\
$\mathrm{Nickel}$ oxide $\left(\mathrm{NiO}_{\mathrm{x}}\right)$ & 4.16 & {$[157]$} \\
$\mathrm{TiO}_{2} / \mathrm{NiO}$ electrodes & 4.78 & {$[158]$} \\
$\mathrm{TiO}_{2}$ nanorod arrays & - & {$[159]$} \\
$\mathrm{Anatase}_{\mathrm{TiO}}$ thin films & 0.61 & {$[160]$} \\
$\mathrm{Al}_{-}$-doped $\mathrm{ZnO}(\mathrm{AZO})$ films & - & {$[161]$} \\
$\mathrm{Thin} \mathrm{TiO}_{2}$ (anatase) films & 0.78 & {$[162]$} \\
$\mathrm{TiO}_{2}$ films on $\mathrm{SnO}_{2}:$ F coated glass & 5.91 & {$[163]$} \\
substrates & & \\
$\mathrm{Al}_{2} \mathrm{O}_{3}$-coated $\mathrm{TiO}_{2}$ electrode &
\end{tabular}

TABLE 7: Materials in DSSC by RF magnetron sputtering methods.

\begin{tabular}{|c|c|c|}
\hline Materials & $\begin{array}{c}\text { Efficiency } \\
\eta(\%)\end{array}$ & Reference \\
\hline $\begin{array}{l}\text { Aluminum-doped zinc oxide (AZO) thin } \\
\text { films on glass substrates }\end{array}$ & $2.91-4.13$ & {$[164]$} \\
\hline Porous $\mathrm{TiO}_{2}$ films on FTO electrode & 4.60 & {$[165]$} \\
\hline Compact $\mathrm{ZnO}$ interlayer & 4.00 & [166] \\
\hline $\mathrm{TiO}_{2}$ covered FTO electrode & - & {$[167]$} \\
\hline $\mathrm{ZnO}: \mathrm{Al}$ thin film & 2.10 & {$[168]$} \\
\hline $\begin{array}{l}\text { Titanium-doped indium-tin-oxide } \\
\text { (Ti:ITO) and indium-tin-oxide (ITO) }\end{array}$ & 3.75 & [169] \\
\hline Indium tin oxide (ITO) & - & {$[170]$} \\
\hline $\begin{array}{l}\text { Aluminum oxynitride }\left(\mathrm{AlO}_{\mathrm{x}} \mathrm{N}_{\mathrm{y}}\right) \text { films on } \\
\text { polyethylene naphthalate }(\mathrm{PEN}) \\
\text { substrates }\end{array}$ & 5.00 & {$[171]$} \\
\hline Triple-layered ITO/ATO/TiO ${ }_{2}$ & 6.29 & {$[172]$} \\
\hline Pt counter electrode & 3.60 & {$[173]$} \\
\hline Columnar-structured rutile $\mathrm{TiO}_{2}$ film & 2.40 & {$[174]$} \\
\hline
\end{tabular}

3.1.3. Pulsed Laser Deposition (PLD). The thin film deposition method used high power laser beams $\left(108 \mathrm{~W} \mathrm{~cm}^{-2}\right)$ as a means of evaporation in ultra high vacuum chambers or gases such as oxygen (Figure 11). The laser is capable of evaporating the target source of heat or inducing photo dissociation. Then, the materials will be converted to plasma atoms, molecules, and chunks and are duly deposited onto the substrate. The film will not be damaged due to the absence of the accumulating of electric charge. The energy beam is regarded as a laser beam, which does not scatter for long distance. The target source decreases the contamination to the lowest level. This method is uncommon in the industry, due to lasers being rather expensive. The advantage of this method is its alacrity and simplicity, that it maintains stoichiometry, that it is crystalline, its well-defined final structures, its high complexity and mixtures materials, its good adhesion, and its compatibility with oxygen and other reactive gases. All these properties could be controlled by laser intensity, substrate temperature, buffer gas pressure, and incident angle of the coating plume. Particulates, composition, and thickness being dependent on the deposition are some of the disadvantages of this process. Despite these considerable advantages, PLD is regarded as being too slow for industrial applications due to three main factors, such as the plasma forwarding directly to the substrate, being nonuniform, depositing in a relatively small area $\left(\sim 1 \mathrm{~cm}^{2}\right)$, and requiring novel materials for the purpose of the optimization of deposition parameters. The novel PLD method called Glancing Angle Pulsed Laser Deposition (GAPLD) [49] is used to prepare porous nanostructure thin films. This process has the strength ability to control the shape of nanostructure, such as porous nanocolumnar film, nanorod arrays with different shapes, nanospring arrays, and multilayer nanostructures. In this method, the substrate is placed above the vapor source at an oblique angle. The composite $\mathrm{TiO}_{2}$ electrodes show an efficiency of $3.80 \%$ [45], whereas the indium-tin oxide nanowires on glass have an efficiency of $0.15 \%$ [50]. The optical properties of ITO and $\mathrm{TiO}_{2}$ single and double layer thin films developed the functional materials for DSSC applications [51], and the large surface area is imperative visà-vis dye-sensitized solar cells (DSSCs) applications [52].

3.1.4. Cathodic Arc Deposition (Arc-PVD). The arc-PVD is one of the ion beam deposition using electrical arc, which produces the blasts ions from the cathode (Figure 12). The high power density produced by the arc has a high level of ionization (30-100\%), multiply charged ions, neutral particles, clusters, and macroparticles (droplets). The reactive gas is used throughout the evaporation procedure, and dissociation, ionization, and excitation could occur during the interaction with the ion flux, which results in a compound film being deposited. Metallic, ceramic, and composite films could be prepared with this method. The advantage of this process is its compatibility with industry, good adhesion of the product, stoichiometry compounds, low temperature, multilayer coating, compact film, uniform film, and low voltage. The inability to coat complex geometries and the utilization of liquid droplets and metal macroparticles are some of the disadvantages of this method [53]. Arc-PVD method is one the methods for fabrication DSSC such as ITO/Cr/DLC (n-type)/Pt (efficiency of 3.30\%) [54], $\mathrm{TiO}_{2}$ nanotube array (efficiency of 1.88\%) [55], and nanocrystalline titania films (efficiency of $0.90 \%$ ) [56].

3.1.5. Thermal Spraying (No High Vacuum). Thermal spraying is one of the coating methods that applies heat by electrical (plasma or arc) and chemical (combustion flame) means to melt the materials with high temperature and spray particles at high speeds on the surface (Figure 13). The liquid material will almost immediately form a film. Thermal spraying 


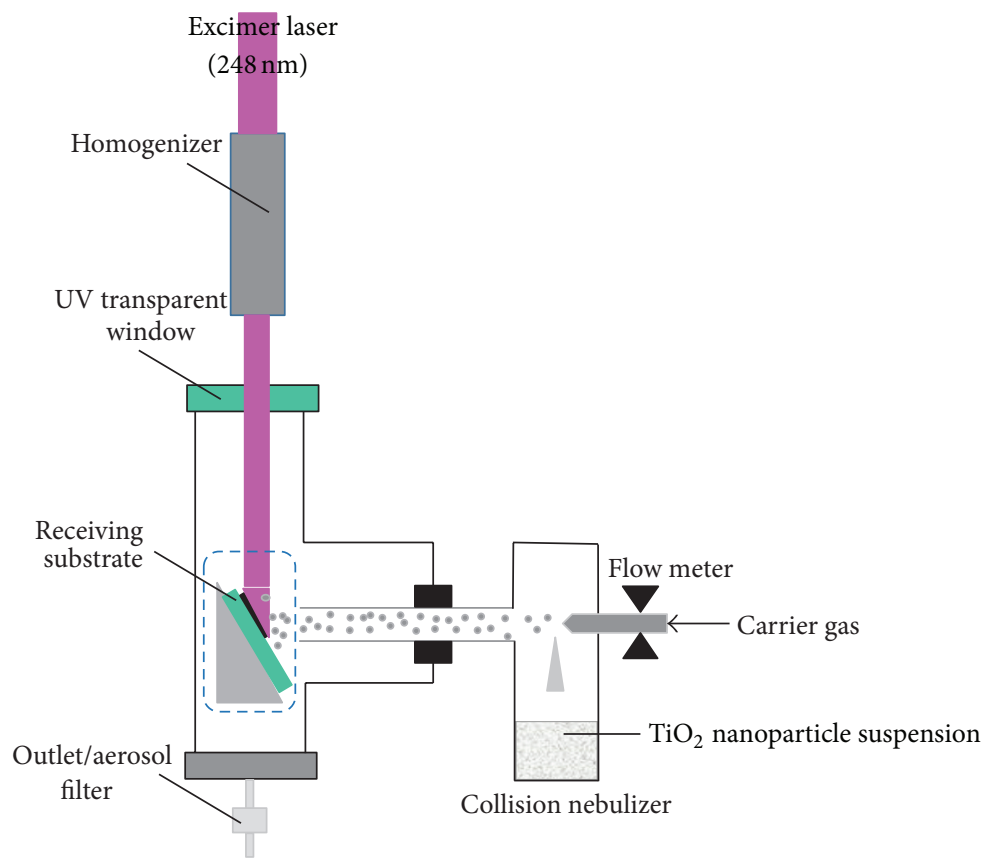

FIGURE 11: Schematic of pulsed laser deposition [45].

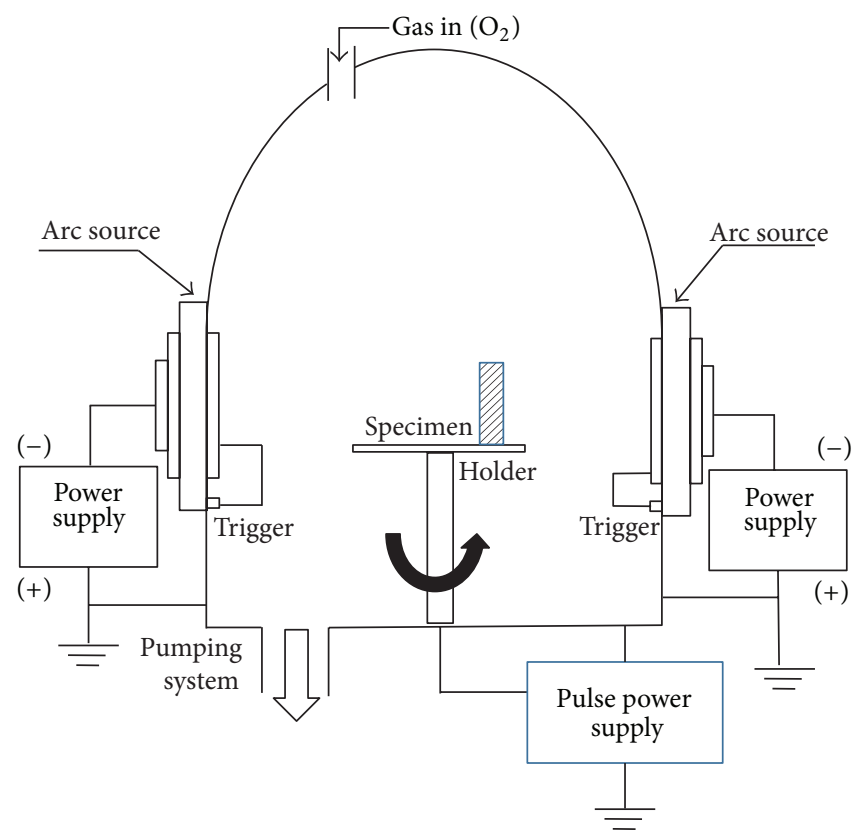

FIGURE 12: Graphic of arc-PVD [46].

included plasma spraying, detonation spraying, wire arc spraying, flame spraying, velocity oxy-fuel coating spraying (HVOF), warm spraying, and cold spraying. The thickness of the deposited films usually ranges from $20 \mu \mathrm{m}$ to several $\mathrm{mm}$, which is indicative of a high deposition rate in a large area relative to other chemical and physical vapor deposition methods. Quite a number of materials are viable for this process, such as metals, alloys, ceramics, plastics, and composites. This process is considered rather efficient in the context of DSSCs, comparable to the doctor blading method [57]. The wide range of materials and substrates, drying process occurring in the spraying step, the formation of the film at low temperatures, and its rather quick processing method are some of the advantages of this method. Meanwhile, some of its disadvantages are the difficulty in controlling the thickness and its relatively low adhesion onto the substrate. There are some examples in DSSC application such as nanocrystalline $\mathrm{TiO}_{2}$ (efficiency of 2.40\%) [58], 


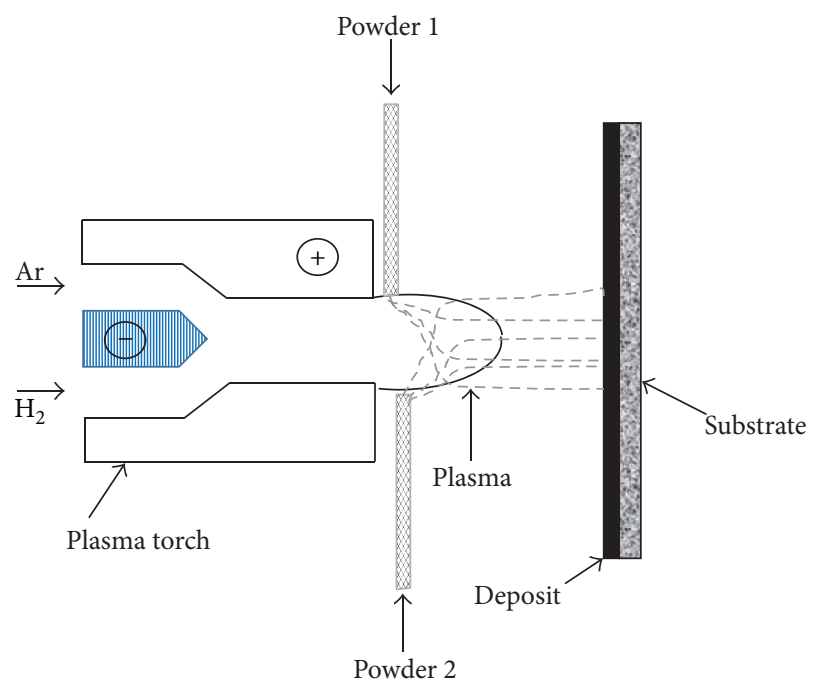

FIGURE 13: Schematic of thermal spraying [47].

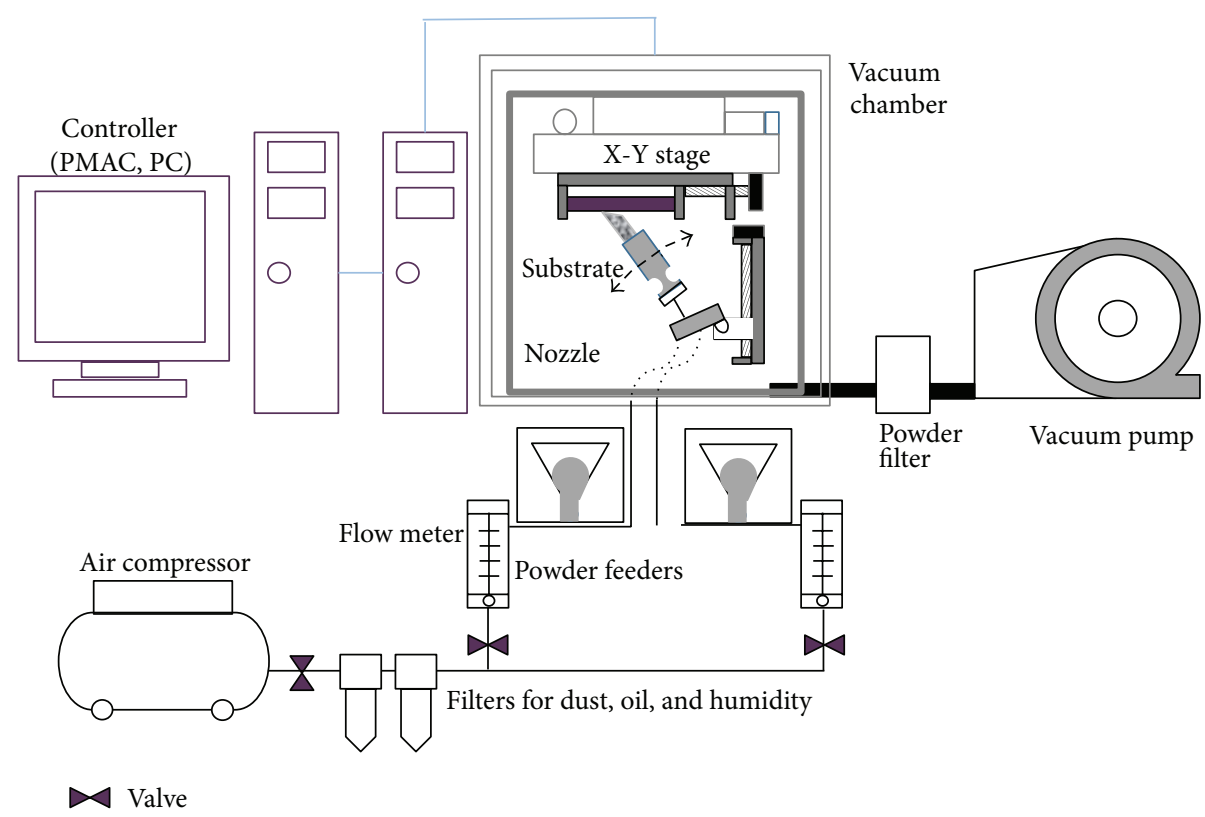

FIGURE 14: Schematic of NPDS [48].

$\mathrm{TiO}_{2}$ films on ITO-PET substrates (efficiency of $2.80 \%$ ) [59], and nanoporous microstructure of $\mathrm{TiO}_{2}$ (efficiency of 7.10\%) [57].

3.1.6. Nanoparticle Deposition System (NPDS). NPDS is a novel method that is used to deposit ceramic and metallic powders on substrates at room temperature, by spraying particles under low temperature and low vacuums, and accelerate particles to subsonic speeds (Figure 14) $[48,60]$. A novel method was applied for the deposition of $\mathrm{TiO}_{2}$ powders using Nanoparticle Deposition System (NPDS) for a dyesensitized solar cell (DSSC). This method could overcome certain limitations in the aerosol deposition method (ADM) and cold gas dynamic spray method (CGDS). The ceramic powder deposited on the substrate by ADM in vacuum condition and metallic powder deposition requires a high pressure of carrier gas using the CGDS method. The ADM method could not be used for metallic powder, due to its low particle velocity [61]. This method could cover a wide range of materials using the supersonic/subsonic nozzle and low-vacuum deposition conditions [60]. Some advantages for this novel process are its viability at room temperature, susceptibility to a variety of materials, high deposition rates, and green fabrication without wet chemicals and binders [62]. NPDS is used to fabricate DSSC, for instance, $\mathrm{TiO}_{2}$ powders on indium tin oxide (ITO) coated polyethylene terephthalate (PET) substrates (efficiency of 0.94\%) [63], 
semiconducting $\mathrm{TiO}_{2}$ powder on indium tin oxide (ITO)coated glass (efficiency of 1.24\%) [60], and crystalline $\mathrm{TiO}_{2}$ powders (efficiency of 2.80\%) [48].

\section{Conclusions and Outlook}

Taking into account the discussion at this point, one can conclude that the choice of method depends on parameters that are regarded as important by the researchers. For example, if film adhesion forms the primary theme of the research, then the thermal spraying and PVD-thermal evaporation methods are unsuitable. If a substrate with a complex shape is subjected to coating, then the spin coating, PVD-thermal evaporation, and Arc-PVD do not meet the proper criteria. In addition, the limitations of precursor's choice in PVD-thermal evaporation and DC Magnetron sputtering are rather obvious.

The deposition methods are dependent on a variety of consideration and numerous criteria, including thin film applications, material characteristics, and process technology. The best deposition lacks a clear guideline and has to take into account the limitations and advantages of different preparations and deposition technology in the context of the materials' and substrates' type, specified application, cost, and requested efficiency, which could assist the researcher(s) in selecting a more appropriate procedure for their respective research.

\section{Conflict of Interests}

The authors declare that there is no conflict of interests regarding the publication of this paper.

\section{Acknowledgments}

The authors would like to thank the UKMDLP-2013-015 and GGPM-2012-027 Research Funds for providing financial support to this study.

\section{References}

[1] N. Asim, K. Sopian, S. Ahmadi et al., "A review on the role of materials science in solar cells," Renewable and Sustainable Energy Reviews, vol. 16, pp. 5834-5847, 2012.

[2] L. Wang, X. Fang, and Z. Zhang, "Design methods for large scale dye-sensitized solar modules and the progress of stability research," Renewable and Sustainable Energy Reviews, vol. 14, no. 9, pp. 3178-3184, 2010.

[3] Y.-D. Zhang, X.-M. Huang, D.-M. Li, Y.-H. Luo, and Q.-B. Meng, "How to improve the performance of Dye-Sensitized Solar Cell modules by light collection," Solar Energy Materials and Solar Cells, vol. 98, pp. 417-423, 2012.

[4] Y.-D. Zhang, X.-M. Huang, Y.-Y. Yang et al., "How to improve the performance of dye-sensitized solar modules by "back leads"'” Solar Energy Materials and Solar Cells, vol. 102, pp. 109113, 2012.

[5] F. Bella, R. Bongiovanni, R. S. Kumar, M. A. Kulandainathan, and A. M. Stephan, "Light cured networks containing metal organic frameworks as efficient and durable polymer electrolytes for Dye-Sensitized Solar Cells," Journal of Materials Chemistry A, vol. 1, pp. 9033-9036, 2013.

[6] D. Pugliese, F. Bella, V. Cauda et al., "A chemometric approach for the sensitization procedure of $\mathrm{ZnO}$ flowerlike microstructures for Dye-Sensitized Solar Cells," ACS Applied Materials \& Interfaces, vol. 5, pp. 11288-11295, 2013.

[7] N. Asim, S. Ahmadi, M. A. Alghoul, F. Y. Hammadi, K. Saeedfar, and K. Sopian, "Research and development aspects on chemical preparation techniques of photoanodes for dye Sensitized solar cells," Journal International Journal of Photoenergy, vol. 2014, Article ID 518156, 2014.

[8] D. B. Hall, P. Underhill, and J. M. Torkelson, "Spin coating of thin and ultrathin polymer films," Polymer Engineering and Science, vol. 38, no. 12, pp. 2039-2045, 1998.

[9] P.n. Equipment, Spin coater, 2011.

[10] G. A. Luurtsema, Spin Coating for Rectangular Substrates, Department of Electrical Engineering and Computer Sciences, University of California, Berkeley, Calif, USA, 1997.

[11] F. C. Krebs, "Fabrication and processing of polymer solar cells: a review of printing and coating techniques," Solar Energy Materials and Solar Cells, vol. 93, no. 4, pp. 394-412, 2009.

[12] P. Yimsiri and M. R. MacKley, "Spin and dip coating of light-emitting polymer solutions: matching experiment with modelling," Chemical Engineering Science, vol. 61, no. 11, pp. 3496-3505, 2006.

[13] K. Antoine de, F. Angela, F. V. Jérôme, P. Adam, and R. Peter, "Colloidal CuInSe 2 nanocrystals thin films of low surface roughness," Advances in Natural Sciences: Nanoscience and Nanotechnology, vol. 4, Article ID 015004, 2013.

[14] L. D. Landau and B. G. Levich, "Dragging of a liquid by a moving plate," Acta Physicochim, URSS, vol. 17, pp. 42-54, 1942.

[15] M. N. Rahaman, Ceramic Processing, CRC/Taylor \& Francis, Boca Raton, Fla, USA, 2007.

[16] L. E. Scriven, "Physics and applications of DIP coating and spin coating," MRS Proceedings, vol. 121, p. 717, 1988.

[17] T. C. Wei, C. C. Wan, and Y. Y. Wang, "Poly (N -vinyl2-pyrrolidone)-capped platinum nanoclusters on indium-tin oxide glass as counterelectrode for Dye-Sensitized Solar Cells," Applied Physics Letters, vol. 88, no. 10, Article ID 103122, 2006.

[18] S. Ito, P. Liska, P. Comte et al., "Control of dark current in photoelectrochemical $\left(\mathrm{TiO}_{2} / \mathrm{I}^{-}-\mathrm{I}_{3}\right)$ and Dye-Sensitized Solar Cells," Chemical Communications, no. 34, pp. 4351-4353, 2005.

[19] C. Industray, Advanced Forming: Advances in Tape Casting Technology, 2004.

[20] R. Mens, P. Adriaensens, L. Lutsen et al., "NMR study of the nanomorphology in thin films of polymer blends used in organic PV devices: MDMO-PPV/PCBM," Journal of Polymer Science A, vol. 46, no. 1, pp. 138-145, 2008.

[21] F. Padinger, C. J. Brabec, T. Fromherz, J. C. Hummelen, and N. S. Sariciftci, "Fabrication of large area photovoltaic devices containing various blends of polymer and fullerene derivatives by using the doctor blade technique," Opto-Electronics Review, vol. 8, no. 4, pp. 280-283, 2000.

[22] C. L. Yu, "Titanium dioxide thick film printing paste for dye sensitized solar cell," in Material Science and Engineering, pp. 175, Case Western Reserve University, 2011.

[23] S. Ito, P. Chen, P. Comte et al., "Fabrication of screenprinting pastes from $\mathrm{TiO}_{2}$ powders for dye-sensitised solar cells," Progress in Photovoltaics: Research and Applications, vol. 15 , no. 7, pp. 603-612, 2007. 
[24] S. Ito, T. N. Murakami, P. Comte et al., "Fabrication of thin film dye sensitized solar cells with solar to electric power conversion efficiency over 10\%," Thin Solid Films, vol. 516, no. 14, pp. 46134619, 2008.

[25] T. N. Murakami, S. Ito, Q. Wang et al., "Highly efficient Dye-Sensitized Solar Cells based on carbon black counter electrodes," Journal of the Electrochemical Society, vol. 153, no. 12, pp. A2255-A2261, 2006.

[26] K. K. Wong, A. Ng, X. Y. Chen et al., "Effect of $\mathrm{ZnO}$ nanoparticle properties on Dye-Sensitized Solar Cell performance," ACS Applied Materials and Interfaces, vol. 4, no. 3, pp. 1254-1261, 2012.

[27] H.-M. Cheng and W.-F. Hsieh, "Electron transfer properties of organic Dye-Sensitized Solar Cells based on indoline sensitizers with ZnO nanoparticles," Nanotechnology, vol. 21, no. 48, Article ID 485202, 2010.

[28] L. Chen, W. Tan, J. Zhang, X. Zhou, X. Zhang, and Y. Lin, "Fabrication of high performance Pt counter electrodes on conductive plastic substrate for flexible Dye-Sensitized Solar Cells," Electrochimica Acta, vol. 55, no. 11, pp. 3721-3726, 2010.

[29] S. Ito, N.-L. C. Ha, G. Rothenberger et al., "High-efficiency (7.2\%) flexible Dye-Sensitized Solar Cells with Ti-metal substrate for nanocrystalline- $\mathrm{TiO}_{2}$ photoanode," Chemical Communications, no. 38, pp. 4004-4006, 2006.

[30] A. Jaworek and A. T. Sobczyk, "Electrospraying route to nanotechnology: an overview," Journal of Electrostatics, vol. 66, no. 3-4, pp. 197-219, 2008.

[31] J. C. Swarbrick, J. B. Taylor, and J. N. O'Shea, "Electrospray deposition in vacuum," Applied Surface Science, vol. 252, no. 15, pp. 5622-5626, 2006.

[32] S. K. Shah, Application of Electrospray Deposition for Efficient and Stable Organic Photovoltaic Devices, School of Advance Studies University of Camerino, 2012.

[33] X. Li, Y. Zhang, Z. Zhang et al., "Electrospraying tuned photoanode structures for Dye-Sensitized Solar Cells with enhanced energy conversion efficiency," Journal of Power Sources, vol. 196, no. 3, pp. 1639-1644, 2011.

[34] G. C. Vougioukalakis, T. Stergiopoulos, G. Kantonis et al., "Terpyridine- and 2,6-dipyrazinylpyridine-coordinated ruthenium(II) complexes: synthesis, characterization and application in $\mathrm{TiO}_{2}$-based Dye-Sensitized Solar Cells," Journal of Photochemistry and Photobiology A, vol. 214, no. 1, pp. 22-32, 2010.

[35] R. Chandrasekhar and K. L. Choy, "Electrostatic spray assisted vapour deposition of fluorine doped tin oxide," Journal of Crystal Growth, vol. 231, no. 1-2, pp. 215-221, 2001.

[36] L. González-García, J. Idígoras, A. R. González-Elipe, A. Barranco, and J. A. Anta, "Charge collection properties of DyeSensitized Solar Cells based on 1-dimensional $\mathrm{TiO}_{2}$ porous nanostructures and ionic-liquid electrolytes," Journal of Photochemistry and Photobiology A, vol. 241, pp. 58-66, 2012.

[37] G. Jimenez-Cadena, E. Comini, M. Ferroni, A. Vomiero, and G. Sberveglieri, "Synthesis of different $\mathrm{ZnO}$ nanostructures by modified PVD process and potential use for Dye-Sensitized Solar Cells," Materials Chemistry and Physics, vol. 124, no. 1, pp. 694-698, 2010.

[38] S. Wang, J. Zhang, S. Chen et al., "Conversion enhancement of flexible Dye-Sensitized Solar Cells based on $\mathrm{TiO}_{2}$ nanotube arrays with $\mathrm{TiO}_{2}$ nanoparticles by electrophoretic deposition," Electrochimica Acta, vol. 56, no. 17, pp. 6184-6188, 2011.

[39] L. González-García, I. González-Valls, M. Lira-Cantu, A. Barranco, and A. R. González-Elipe, "Aligned $\mathrm{TiO}_{2}$ nanocolumnar layers prepared by PVD-GLAD for transparent dye sensitized solar cells," Energy and Environmental Science, vol. 4, no. 9, pp. 3426-3435, 2011.

[40] M. C. Sharma, B. Tripathi, S. Kumar, S. Srivastava, and Y. K. Vijay, "Low cost CuInSe2 thin films production by stacked elemental layers process for large area fabrication of solar cell application," Materials Chemistry and Physics, vol. 131, no. 3, pp. 600-604, 2012.

[41] N. S. Xu and S. E. Huq, "Novel cold cathode materials and applications," Materials Science and Engineering R, vol. 48, no. 2-5, 2005.

[42] I. P. Jain and G. Agarwal, "Ion beam induced surface and interface engineering," Surface Science Reports, vol. 66, no. 3-4, pp. 77-172, 2011.

[43] A. Barron, "Applying metallization by sputtering," 2010, http://cnx.org/content/m33800/1.3/.

[44] H. Wender, P. Migowski, A. F. Feil, S. R. Teixeira, and J. Dupont, "Sputtering deposition of nanoparticles onto liquid substrates: recent advances and future trends," Coordination Chemistry Reviews, vol. 257, no. 17-18, pp. 2468-2248, 2013.

[45] H. Pan, S. H. Ko, N. Misra, and C. P. Grigoropoulos, "Laser annealed composite titanium dioxide electrodes for DyeSensitized Solar Cells on glass and plastics," Applied Physics Letters, vol. 94, no. 7, Article ID 071117, 2009.

[46] W.-Y. Ho, M.-H. Chan, K.-S. Yao, C.-L. Chang, D.-Y. Wang, and C.-H. Hsu, "Characteristics of chromium-doped titanium oxide coatings synthesized by cathodic arc deposition," Thin Solid Films, vol. 516, no. 23, pp. 8530-8536, 2008.

[47] T. Zhang, Y. Bao, and D. T. Gawne, "Process model of plasma enamelling," Journal of the European Ceramic Society, vol. 23, no. 7, pp. 1019-1026, 2003.

[48] Y.-H. Kim, M.-S. Kim, K.-S. Kim, S.-H. Ahn, and C. S. Lee, "Deposition of $\mathrm{TiO}_{2}$ layers for Dye-Sensitized Solar Cells using nano-particle deposition system," Current Applied Physics, vol. 11, no. 1, pp. S122-S126, 2011.

[49] K. Robbie and M. J. Brett, "Sculptured thin films and glancing angle deposition: growth mechanics and applications," Journal of Vacuum Science and Technology A, vol. 15, no. 3, pp. 14601465, 1997.

[50] E. Joanni, R. Savu, M. de Sousa Góes et al., "Dye-Sensitized Solar Cell architecture based on indium-tin oxide nanowires coated with titanium dioxide," Scripta Materialia, vol. 57, no. 3, pp. 277-280, 2007.

[51] F. Fotsa-Ngaffo, A. P. Caricato, and F. Romano, "Optical properties of ITO/TiO ${ }_{2}$ single and double layer thin films deposited by RPLAD," Applied Surface Science, vol. 255, no. 24, pp. 96849687, 2009

[52] F. F. Ngaffo, A. P. Caricato, M. Fernandez, M. Martino, and F. Romano, "Structural properties of single and multilayer ITO and $\mathrm{TiO}_{2}$ films deposited by reactive pulsed laser ablation deposition technique," Applied Surface Science, vol. 253, no. 15, pp. 6508-6511, 2007.

[53] P. A. Lindfors, W. M. Mularie, and G. K. Wehner, "Cathodic arc deposition technology," Surface and Coatings Technology, vol. 29, no. 4, pp. 275-290, 1986.

[54] S.-F. Wang, K. K. Rao, T. C. K. Yang, and H.-P. Wang, "Investigation of nitrogen doped diamond like carbon films as counter electrodes in dye sensitized solar cells," Journal of Alloys and Compounds, vol. 509, no. 5, pp. 1969-1974, 2011.

[55] C.-H. Chen, K.-C. Chen, and J.-L. He, “Transparent conducting oxide glass grown with $\mathrm{TiO}_{2}$-nanotube array for Dye-Sensitized 
Solar Cell," Current Applied Physics, vol. 10, no. 2, pp. S176-S179, 2010.

[56] X. Cheng, P. Zeng, S. Hu, T. Kuang, G. Xie, and F. Gao, "Preparation and characterization of $\mathrm{TiO}_{2}$ photoelectrode codoped with aluminum and boron and its application in Dye-Sensitized Solar Cell," Rare Metals, vol. 25, no. 6, pp. 190-194, 2006.

[57] S.-Q. Fan, C.-J. Li, C.-X. Li, G.-J. Liu, G.-J. Yang, and L.-Z. Zhang, "Preliminary study of performance of Dye-Sensitized Solar Cell of nano- $\mathrm{TiO}_{2}$ coating deposited by vacuum cold spraying," Materials Transactions, vol. 47, no. 7, pp. 1703-1709, 2006.

[58] S. Q. Fan, C. J. Li, G. J. Yang, L. Z. Zhang, J. C. Gao, and Y. X. $\mathrm{Xi}$, "Fabrication of nano- $\mathrm{TiO}_{2}$ coating for Dye-Sensitized Solar Cell by vacuum cold spraying at room temperature," Journal of Thermal Spray Technology, vol. 16, pp. 893-897, 2007.

[59] J. Halme, J. Saarinen, and P. Lund, "Spray deposition and compression of $\mathrm{TiO}_{2}$ nanoparticle films for Dye-Sensitized Solar Cells on plastic substrates," Solar Energy Materials and Solar Cells, vol. 90, no. 7-8, pp. 887-899, 2006.

[60] M.-S. Kim, D.-M. Chun, J.-O. Choi et al., "Room temperature deposition of $\mathrm{TiO}_{2}$ using nano particle deposition system (NPDS): Application to Dye-Sensitized Solar Cell (DSSC)," International Journal of Precision Engineering and Manufacturing, vol. 12, no. 4, pp. 749-752, 2011.

[61] J. Akedo, "Aerosol deposition of ceramic thick films at room temperature: densification mechanism of ceramic layers," Journal of the American Ceramic Society, vol. 89, no. 6, pp. 1834-1839, 2006.

[62] D. M. Chun, M. H. Kim, J. C. Lee, and S. H. Ahn, “TiO ${ }_{2}$ coating on metal and polymer substrates by nano-particle deposition system (NPDS)," CIRP Annals_Manufacturing Technology, vol. 57, no. 1, pp. 551-554, 2008.

[63] M. S. Kim, D. M. Chun, J. O. Choi et al., "Dry-spray deposition of $\mathrm{TiO}_{2}$ for a Flexible Dye-Sensitized Solar Cell (DSSC) Using a Nanoparticle Deposition System (NPDS)," Journal of Nanoscience and Nanotechnology, vol. 12, pp. 3384-3388, 2012.

[64] P. Suresh, P. Balaraju, S. K. Sharma, M. S. Roy, and G. D. Sharma, "Photovoltaic devices based on PPHT: ZnO and dye-sensitized PPHT: ZnO thin films," Solar Energy Materials and Solar Cells, vol. 92, no. 8, pp. 900-908, 2008.

[65] C. S. Chou, C. S. Chou, Y. T. Kuo, and C. P. Wang, "Preparation of a working electrode with a conducting PEDOT:PSS film and its applications in a Dye-Sensitized Solar Cell," Advanced Powder Technology, vol. 24, pp. 336-343, 2013.

[66] M. McCune, W. Zhang, and Y. Deng, "High efficiency DyeSensitized Solar Cells based on three-dimensional multilayered $\mathrm{ZnO}$ nanowire arrays with "Caterpillar-like" structure," Nano Letters, vol. 12, pp. 3656-3662, 2012.

[67] S.-Y. Hsu, C.-H. Tsai, C.-Y. Lu et al., "Nanoporous platinum counter electrodes by glancing angle deposition for DyeSensitized Solar Cells," Organic Electronics, vol. 13, no. 5, pp. 856-863, 2012.

[68] L. J. Larsen, D. D. Tune, P. Kemppinen, K. N. Winzenberg, S. E. Watkins, and J. G. Shapter, "Increased performance of single walled carbon nanotube photovoltaic cells through the addition of dibenzo[b,def]chrysene derivative," Journal of Photochemistry and Photobiology A, vol. 235, pp. 72-76, 2012.

[69] B. Munkhbayar, S. Hwang, J. Kim et al., "Photovoltaic performance of Dye-Sensitized Solar Cells with various MWCNT counter electrode structures produced by different coating methods," Electrochimica Acta, vol. 80, pp. 100-107, 2012.
[70] L. Song, P. Du, X. Shao, H. Cao, Q. Hui, and J. Xiong, "Effects of hydrochloric acid treatment of $\mathrm{TiO}_{2}$ nanoparticles/nanofibers bilayer film on the photovoltaic properties of Dye-Sensitized Solar Cells," Materials Research Bulletin, vol. 48, pp. 978-982, 2013.

[71] W. Zeng, G. Fang, X. Wang et al., "Hierarchical porous nanocarbon composite: effective fabrication and application in dye sensitized solar cells," Journal of Power Sources, vol. 229, pp. 102111, 2013.

[72] S. H. Park, K. H. Shin, J. Y. Kim et al., "The application of camphorsulfonic acid doped polyaniline films prepared on TCO-free glass for counter electrode of bifacial Dye-Sensitized Solar Cells," Journal of Photochemistry and Photobiology A, vol. 245, pp. 1-8, 2012.

[73] J. S. Ni, C. Y. Hung, K. Y. Liu, Y. H. Chang, K. C. Ho, and K. F. Lin, "Effects of tethering alkyl chains for amphiphilic ruthenium complex dyes on their adsorption to titanium oxide and photovoltaic properties," Journal of Colloid and Interface Science, vol. 386, pp. 359-365, 2012.

[74] Z. Qin, Y. Huang, Q. Liao, Z. Zhang, X. Zhang, and Y. Zhang, "Stability improvement of the $\mathrm{ZnO}$ nanowire array electrode modified with $\mathrm{Al}_{2} \mathrm{O}_{3}$ and $\mathrm{SiO}_{2}$ for Dye-Sensitized Solar Cells," Materials Letters, vol. 70, pp. 177-180, 2012.

[75] Z. Qin, Y. Huang, J. Qi, L. Qu, and Y. Zhang, "Improvement of the performance and stability of the $\mathrm{ZnO}$ nanoparticulate film electrode by surface modification for Dye-Sensitized Solar Cells," Colloids and Surfaces A, vol. 386, no. 1-3, pp. 179-184, 2011.

[76] C.-C. Chang, M.-T. Jiang, C.-L. Chang, and C.-L. Lin, "Preparation and characterization of poly(3,4-ethylenedioxythiophene)poly(styrene sulfonate) composite thin films highly loaded with platinum nanoparticles," Materials Chemistry and Physics, vol. 127, no. 3, pp. 440-445, 2011.

[77] C.-S. Chou, Y.-J. Lin, R.-Y. Yang, and K.-H. Liu, "Preparation of $\mathrm{TiO}_{2} / \mathrm{NiO}$ composite particles and their applications in DyeSensitized Solar Cells," Advanced Powder Technology, vol. 22, no. 1, pp. 31-42, 2011.

[78] Y. Liu, X. Sun, Q. Tai et al., "Efficiency enhancement in DyeSensitized Solar Cells by interfacial modification of conducting glass/mesoporous $\mathrm{TiO}_{2}$ using a novel $\mathrm{ZnO}$ compact blocking film," Journal of Power Sources, vol. 196, no. 1, pp. 475-481, 2011.

[79] Y. Liu, X. Sun, Q. Tai et al., "Influences on photovoltage performance by interfacial modification of FTO/mesoporous $\mathrm{TiO}_{2}$ using $\mathrm{ZnO}$ and $\mathrm{TiO}_{2}$ as the compact film," Journal of Alloys and Compounds, vol. 509, no. 37, pp. 9264-9270, 2011.

[80] Y. G. Seo, M. A. Kim, H. Lee, and W. Lee, "Solution processed thin films of non-aggregated $\mathrm{TiO}_{2}$ nanoparticles prepared by mild solvothermal treatment," Solar Energy Materials and Solar Cells, vol. 95, no. 1, pp. 332-335, 2011.

[81] C.-M. Chen, H.-S. Shiu, S.-J. Cherng, and T.-C. Wei, "Preparation of polymer film of micro-porous or island-like structure and its application in Dye-Sensitized Solar Cell," Journal of Power Sources, vol. 188, no. 1, pp. 319-322, 2009.

[82] W. Hong, Y. Xu, G. Lu, C. Li, and G. Shi, "Transparent graphene/PEDOT-PSS composite films as counter electrodes of Dye-Sensitized Solar Cells," Electrochemistry Communications, vol. 10, no. 10, pp. 1555-1558, 2008.

[83] M. Biancardo, K. West, and F. C. Krebs, "Quasi-solid-state DyeSensitized Solar Cells: Pt and PEDOT:PSS counter electrodes applied to gel electrolyte assemblies," Journal of Photochemistry and Photobiology A, vol. 187, no. 2-3, pp. 395-401, 2007. 
[84] S. H. Kang, J.-Y. Kim, Y.-K. Kim, and Y.-E. Sung, "Effects of the incorporation of carbon powder into nanostructured $\mathrm{TiO}_{2}$ film for Dye-Sensitized Solar Cell," Journal of Photochemistry and Photobiology A, vol. 186, no. 2-3, pp. 234-241, 2007.

[85] N. Fukuri, Y. Saito, W. Kubo et al., "Performance improvement of solid-state Dye-Sensitized Solar Cells fabricated using poly(3,4-ethylenedioxythiophene) and amphiphilic sensitizing dye," Journal of the Electrochemical Society, vol. 151, no. 10, pp. A1745-A1748, 2004.

[86] S. Chappel and A. Zaban, "Nanoporous $\mathrm{SnO}_{2}$ electrodes for Dye-Sensitized Solar Cells: improved cell performance by the synthesis of $18 \mathrm{~nm} \mathrm{SnO}_{2}$ colloids," Solar Energy Materials and Solar Cells, vol. 71, no. 2, pp. 141-152, 2002.

[87] J. Liu, Y. Wang, and D. D. Sun, "Oleic acid-assisted exfoliated few layer graphene films as counter electrode in Dye-Sensitized Solar Cell," Journal of Alloys and Compounds, vol. 545, pp. 99104, 2012.

[88] I.-K. Ding, J. Melas-Kyriazi, N.-L. Cevey-Ha et al., "Deposition of hole-transport materials in solid-state Dye-Sensitized Solar Cells by doctor-blading," Organic Electronics, vol. 11, no. 7, pp. 1217-1222, 2010.

[89] W. Sun, X. Sun, T. Peng et al., "A low cost mesoporous carbon $/ \mathrm{SnO}_{2} / \mathrm{TiO}_{2}$ nanocomposite counter electrode for DyeSensitized Solar Cells," Journal of Power Sources, vol. 201, pp. 402-407, 2012.

[90] S. Ameen, M. S. Akhtar, H.-K. Seo, Y. S. Kim, and H. S. Shin, "Influence of $\mathrm{Sn}$ doping on $\mathrm{ZnO}$ nanostructures from nanoparticles to spindle shape and their photoelectrochemical properties for dye sensitized solar cells," Chemical Engineering Journal, vol. 187, pp. 351-356, 2012.

[91] R. Marczak, F. Werner, R. Ahmad, V. Lobaz, D. M. Guldi, and W. Peukert, "Detailed investigations of $\mathrm{ZnO}$ photoelectrodes preparation for dye sensitized solar cells," Langmuir, vol. 27, no. 7, pp. 3920-3929, 2011.

[92] K. Miettunen, M. Toivola, G. Hashmi, J. Salpakari, I. Asghar, and P. Lund, "A carbon gel catalyst layer for the roll-to-roll production of dye solar cells," Carbon, vol. 49, no. 2, pp. 528532, 2011.

[93] V. M. Guerin, C. Magne, T. Pauporté, T. Le Bahers, and J. Rathousky, "Electrodeposited nanoporous versus nanoparticulate $\mathrm{ZnO}$ films of similar roughness for Dye-Sensitized Solar Cell applications," ACS Applied Materials and Interfaces, vol. 2, no. 12, pp. 3677-3685, 2010.

[94] T. Yamaguchi, N. Tobe, D. Matsumoto, T. Nagai, and H. Arakawa, "Highly efficient plastic-substrate Dye-Sensitized Solar Cells with validated conversion efficiency of 7.6\%," Solar Energy Materials and Solar Cells, vol. 94, no. 5, pp. 812-816, 2010.

[95] J. Chen, K. Li, Y. Luo et al., "A flexible carbon counter electrode for Dye-Sensitized Solar Cells," Carbon, vol. 47, no. 11, pp. 27042708, 2009.

[96] K. Li, Y. Luo, Z. Yu, M. Deng, D. Li, and Q. Meng, "Low temperature fabrication of efficient porous carbon counter electrode for Dye-Sensitized Solar Cells," Electrochemistry Communications, vol. 11, no. 7, pp. 1346-1349, 2009.

[97] J. H. Park, Y. Jun, H.-G. Yun, S.-Y. Lee, and M. G. Kang, "Fabrication of an efficient Dye-Sensitized Solar Cell with stainless steel substrate," Journal of the Electrochemical Society, vol. 155, no. 7, pp. F145-F149, 2008.

[98] L. Yang, Y. Lin, J. Jia, X. Xiao, X. Li, and X. Zhou, "Light harvesting enhancement for Dye-Sensitized Solar Cells by novel anode containing cauliflower-like $\mathrm{TiO}_{2}$ spheres," Journal of Power Sources, vol. 182, no. 1, pp. 370-376, 2008.

[99] X. Liu, Y. Luo, H. Li et al., "Room temperature fabrication of porous $\mathrm{ZnO}$ photoelectrodes for flexible Dye-Sensitized Solar Cells," Chemical Communications, no. 27, pp. 2847-2849, 2007.

[100] T. Miyasaka, M. Ikegami, and Y. Kijitori, "Photovoltaic performance of plastic dye-sensitized electrodes prepared by lowtemperature binder-free coating of mesoscopic titania," Journal of the Electrochemical Society, vol. 154, no. 5, pp. A455-A461, 2007.

[101] M. Quintana, T. Edvinsson, A. Hagfeldt, and G. Boschloo, "Comparison of dye-sensitized $\mathrm{ZnO}$ and $\mathrm{TiO}_{2}$ solar cells: studies of charge transport and carrier lifetime," Journal of Physical Chemistry C, vol. 111, no. 2, pp. 1035-1041, 2007.

[102] R. Senadeera, N. Fukuri, Y. Saito, T. Kitamura, Y. Wada, and S. Yanagida, "Volatile solvent-free solid-state polymer-sensitized $\mathrm{TiO}_{2}$ solar cells with poly(3,4-ethylenedioxythiophene) as a hole-transporting medium," Chemical Communications, no. 17, pp. 2259-2261, 2005.

[103] Y. Saito, S. Kambe, T. Kitamura, Y. Wada, and S. Yanagida, "Morphology control of mesoporous $\mathrm{TiO}_{2}$ nanocrystalline films for performance of Dye-Sensitized Solar Cells," Solar Energy Materials and Solar Cells, vol. 83, no. 1, pp. 1-13, 2004.

[104] H. Lindström, A. Holmberg, E. Magnusson, L. Malmqvist, and A. Hagfeldt, "A new method to make dye-sensitized nanocrystalline solar cells at room temperature," Journal of Photochemistry and Photobiology A, vol. 145, no. 1-2, pp. 107-112, 2001.

[105] F. Bella, J. R. Nair, and C. Gerbaldi, “Towards green, efficient and durable quasi-solid Dye-Sensitized Solar Cells integrated with a cellulose-based gel-polymer electrolyte optimized by a chemometric DoE approach," RSC Advances, vol. 3, pp. 1599316001, 2013.

[106] Y. Gong, C. Li, X. Huang et al., "Simple method for manufacturing Pt counter electrodes on conductive plastic substrates for Dye-Sensitized Solar Cells," ACS Applied Materials \& Interfaces, vol. 5, pp. 795-800, 2013.

[107] A. Umar, "Growth of comb-like $\mathrm{ZnO}$ nanostructures for DyeSensitized Solar Cells applications," Nanoscale Research Letters, vol. 4, no. 9, pp. 1004-1008, 2009.

[108] L. Guo, Synthesis of zinc oxide fiber and its application in dye sensitized solar cells [M.S. thesis], Miami University, Oxford, Ohio, USA, 2010.

[109] S. Futemvong, A. Pengpad, N. Hongsith, D. Wongratanaphisan, A. Gardchareon, and S. Choopun, "Effect of nickel oxide thin films on photoconversion efficiency in zinc oxide DyeSensitized Solar Cells," Materials Science Forum, vol. 695, pp. 509-512, 2011.

[110] Y. Wang, Arrays of ZnO Nanowires for Photovoltaic Devices, Department of Physics and Materials Science, City University of Hong Kong, 2009.

[111] C. Y. Neo and J. Ouyang, "Precise modification of the interface between titanium dioxide and electrolyte of Dye-Sensitized Solar Cells with oxides deposited by thermal evaporation of metals and subsequent oxidation," Journal of Power Sources, vol. 196, no. 23, pp. 10538-10542, 2011.

[112] G. J. Fodjouong, Y. Feng, M. Sangare, and X. Huang, "Synthesis of $\mathrm{ZnO}$ nanostructure films by thermal evaporation approach and their application in Dye-Sensitized Solar Cells," Materials Science in Semiconductor Processing, vol. 16, pp. 652-658, 2013. 
[113] S. Li, X. Zhang, X. Jiao, and H. Lin, "One-step large-scale synthesis of porous $\mathrm{ZnO}$ nanofibers and their application in Dye-Sensitized Solar Cells," Materials Letters, vol. 65, no. 19-20, pp. 2975-2978, 2011.

[114] B. E. Hardin, W. Gaynor, I.-K. Ding, S.-B. Rim, P. Peumans, and M. D. McGehee, "Laminating solution-processed silver nanowire mesh electrodes onto solid-state Dye-Sensitized Solar Cells," Organic Electronics, vol. 12, no. 6, pp. 875-879, 2011.

[115] F. Bella, E. D. Ozzello, S. Bianco, and R. Bongiovanni, "Photopolymerization of acrylic/methacrylic gel'polymer electrolyte membranes for Dye-Sensitized Solar Cells," Chemical Engineering Journal, vol. 225, pp. 873-879, 2013.

[116] Y.-G. Kim, C.-H. Shim, D.-H. Kim, H. J. Lee, and H.-J. Lee, "Fabrication of transparent conductive oxide-less DyeSensitized Solar Cells consisting of Ti electrodes by electronbeam evaporation process," Thin Solid Films, vol. 520, no. 6, pp. 2257-2260, 2012.

[117] H.-B. Kim, D.-W. Park, J.-P. Jeun, S.-H. Oh, Y.-C. Nho, and P.-H. Kang, "Effects of electron beam irradiation on the photoelectrochemical properties of $\mathrm{TiO}_{2}$ film for DSSCs," Radiation Physics and Chemistry, vol. 81, pp. 954-957, 2012.

[118] M. Manca, F. Malara, L. Martiradonna et al., "Charge recombination reduction in Dye-Sensitized Solar Cells by means of an electron beam-deposited $\mathrm{TiO}_{2}$ buffer layer between conductive glass and photoelectrode," Thin Solid Films, vol. 518, no. 23, pp. 7147-7151, 2010.

[119] M. Shaheer Akhtar, D.-J. Choi, S.-K. Lee, and O.-B. Yang, "Effect of electron beam irradiation on the electrochemical properties of heteropolyacid-polyethylene oxide composite electrolyte for Dye-Sensitized Solar Cell," Current Applied Physics, vol. 10, no. 2, pp. S161-S164, 2010.

[120] M. K. Parvez, G. M. Yoo, J. H. Kim, M. J. Ko, and S. R. Kim, "Comparative study of plasma and ion-beam treatment to reduce the oxygen vacancies in $\mathrm{TiO}_{2}$ and recombination reactions in Dye-Sensitized Solar Cells," Chemical Physics Letters, vol. 495, no. 1-3, pp. 69-72, 2010.

[121] G. K. Kiema, M. J. Colgan, and M. J. Brett, "Dye sensitized solar cells incorporating obliquely deposited titanium oxide layers," Solar Energy Materials and Solar Cells, vol. 85, no. 3, pp. 321331, 2005.

[122] M.-S. Wong, M.-F. Lee, C.-L. Chen, and C.-H. Huang, "Vapor deposited sculptured nano-porous titania films by glancing angle deposition for efficiency enhancement in Dye-Sensitized Solar Cells," Thin Solid Films, vol. 519, no. 5, pp. 1717-1722, 2010.

[123] H.-Y. Yang, M.-F. Lee, C.-H. Huang, Y.-S. Lo, Y.-J. Chen, and M.-S. Wong, "Glancing angle deposited titania films for DyeSensitized Solar Cells," Thin Solid Films, vol. 518, no. 5, pp. 1590$1594,2009$.

[124] B.-L. Chen, H. Hu, Q.-D. Tai et al., "An inverted fabrication method towards a flexible dye sensitized solar cell based on a free-standing $\mathrm{TiO}_{2}$ nanowires membrane," Electrochimica Acta, vol. 59, pp. 581-586, 2012.

[125] R. Gazia, A. Chiodoni, S. Bianco et al., "An easy method for the room-temperature growth of spongelike nanostructured $\mathrm{Zn}$ films as initial step for the fabrication of nanostructured $\mathrm{ZnO}$," Thin Solid Films, vol. 524, pp. 107-112, 2012.

[126] O. Lupan, V. M. Guérin, L. Ghimpu, I. M. Tiginyanu, and T. Pauporté, "Nanofibrous-like $\mathrm{ZnO}$ layers deposited by magnetron sputtering and their integration in Dye-Sensitized Solar Cells," Chemical Physics Letters, vol. 550, pp. 125-129, 2012.
[127] H. Seo, M. K. Son, S. Park, H. J. Kim, and M. Shiratani, “The blocking effect of charge recombination by sputtered and acidtreated $\mathrm{ZnO}$ thin film in Dye-Sensitized Solar Cells," Journal of Photochemistry and Photobiology A, vol. 248, pp. 50-54, 2012.

[128] B. Yoo, M. K. Lim, and K.-J. Kim, "Application of Pt sputterdeposited counter electrodes based on micro-patterned ITO glass to quasi-solid state Dye-Sensitized Solar Cells," Current Applied Physics, vol. 12, pp. 1302-1306, 2012.

[129] J. Kim, H. Choi, C. Nahm et al., "The effect of a blocking layer on the photovoltaic performance in CdS quantum-dot-sensitized solar cells," Journal of Power Sources, vol. 196, no. 23, pp. 1052610531, 2011.

[130] M. A. Bissett, I. Köper, J. S. Quinton, and J. G. Shapter, “Dendron growth from vertically aligned single-walled carbon nanotube thin layer arrays for photovoltaic devices," Physical Chemistry Chemical Physics, vol. 13, no. 13, pp. 6059-6064, 2011.

[131] W. Chen, Y. Qiu, K. Yan, and S. Yang, "Surfactant directed self-assembly of size-tunable mesoporous titanium dioxide microspheres and their application in quasi-solid state DyeSensitized Solar Cells," Journal of Power Sources, vol. 196, no. 24, pp. 10806-10816, 2011.

[132] L.-Y. Lin, C.-P. Lee, R. V. R.vittal, and K.-C. Ho, "Improving the durability of Dye-Sensitized Solar Cells through back illumination," Journal of Power Sources, vol. 196, no. 3, pp. 16711676, 2011.

[133] K. Miettunen, I. Asghar, X. Ruan, J. Halme, T. Saukkonen, and P. Lund, "Stabilization of metal counter electrodes for dye solar cells," Journal of Electroanalytical Chemistry, vol. 653, no. 1-2, pp. 93-99, 2011.

[134] Y. S. Park and H.-K. Kim, “The effects of annealing temperature on the characteristics of carbon counter electrodes for DyeSensitized Solar Cells," Current Applied Physics, vol. 11, no. 4, pp. 989-994, 2011.

[135] C.-C. Yang, H. Q. Zhang, and Y. R. Zheng, "DSSC with a novel Pt counter electrodes using pulsed electroplating techniques," Current Applied Physics, vol. 11, no. 1, pp. S147-S153, 2011.

[136] M.-H. Yeh, C.-P. Lee, L.-Y. Lin et al., "A composite poly(3,3diethyl-3,4-dihydro-2H-thieno-[3,4-b][1,4]-dioxepine) and $\mathrm{Pt}$ film as a counter electrode catalyst in Dye-Sensitized Solar Cells," Electrochimica Acta, vol. 56, no. 17, pp. 6157-6164, 2011.

[137] Y.-L. Lee, C.-L. Chen, L.-W. Chong, C.-H. Chen, Y.-F. Liu, and C.-F. Chi, "A platinum counter electrode with high electrochemical activity and high transparency for Dye-Sensitized Solar Cells," Electrochemistry Communications, vol. 12, no. 11, pp. 1662-1665, 2010.

[138] D. D. Tune, B. S. Flavel, J. S. Quinton, A. V. Ellis, and J. G. Shapter, "Single walled carbon nanotube network electrodes for dye solar cells," Solar Energy Materials and Solar Cells, vol. 94, no. 10, pp. 1665-1672, 2010.

[139] H. Chang and Y.-J. Lo, "Pomegranate leaves and mulberry fruit as natural sensitizers for Dye-Sensitized Solar Cells," Solar Energy, vol. 84, no. 10, pp. 1833-1837, 2010.

[140] M. F. Hossain and T. Takahashi, "Microstructured ZnO photoelectrode grown on the sputter-deposited $\mathrm{ZnO}$ passivatinglayer for improving the photovoltaic performances," Materials Chemistry and Physics, vol. 124, no. 2-3, pp. 940-945, 2010.

[141] C.-H. Zhou, Y. Yang, J. Zhang et al., "Enhanced electrochemical performance of the counterelectrode of dye sensitized solar cells by sandblasting," Electrochimica Acta, vol. 54, no. 23, pp. 5320$5325,2009$. 
[142] S. Biswas, M. F. Hossain, and T. Takahashi, "Fabrication of Grätzel solar cell with $\mathrm{TiO}_{2} / \mathrm{CdS}$ bilayered photoelectrode," Thin Solid Films, vol. 517, no. 3, pp. 1284-1288, 2008.

[143] M. F. Hossain, S. Biswas, and T. Takahashi, "The effect of sputterdeposited $\mathrm{TiO}_{2}$ passivating layer on the performance of DyeSensitized Solar Cells based on sol-gel derived photoelectrode," Thin Solid Films, vol. 517, no. 3, pp. 1294-1300, 2008.

[144] H. Gao, G. Fang, M. Wang et al., "The effect of growth conditions on the properties of $\mathrm{ZnO}$ nanorod Dye-Sensitized Solar Cells," Materials Research Bulletin, vol. 43, no. 12, pp. 33453351, 2008.

[145] Y.-M. Sung and D.-W. Han, “Transparent conductive titaniumdoped indium oxide films prepared by a magnetic null discharge sputter source," Vacuum, vol. 83, no. 1, pp. 161-165, 2008.

[146] J. Xia, N. Masaki, K. Jiang, and S. Yanagida, "Deposition of a thin film of $\mathrm{TiOx}$ from a titanium metal target as novel blocking layers at conducting glass $/ \mathrm{TiO}_{2}$ interfaces in ionic liquid mesoscopic $\mathrm{TiO}_{2}$ Dye-Sensitized Solar Cells," Journal of Physical Chemistry B, vol. 110, no. 50, pp. 25222-25228, 2006.

[147] M. K. Nazeeruddin, F. De Angelis, S. Fantacci et al., "Combined experimental and DFT-TDDFT computational study of photoelectrochemical cell ruthenium sensitizers," Journal of the American Chemical Society, vol. 127, no. 48, pp. 16835-16847, 2005.

[148] T. Ma, X. Fang, M. Akiyama, K. Inoue, H. Noma, and E. Abe, "Properties of several types of novel counter electrodes for DyeSensitized Solar Cells," Journal of Electroanalytical Chemistry, vol. 574, no. 1, pp. 77-83, 2004.

[149] K. Imoto, K. Takahashi, T. Yamaguchi, T. Komura, J.-I. Nakamura, and K. Murata, "High-performance carbon counter electrode for Dye-Sensitized Solar Cells," Solar Energy Materials and Solar Cells, vol. 79, no. 4, pp. 459-469, 2003.

[150] Y. Saito, T. Kitamura, Y. Wada, and S. Yanagida, "Application of poly(3,4-ethylenedioxythiophene) to counter electrode in DyeSensitized Solar Cells," Chemistry Letters, no. 10, pp. 1060-1061, 2002.

[151] Y. T. Kim, J. Park, and J. Choi, "Sputter-deposited ZnO thin films consisting of nano-networks for binder-free Dye-Sensitized Solar Cells," Current Applied Physics, vol. 13, pp. 381-385, 2013.

[152] M. K. Son, H. Seo, S. K. Kim et al., "Improved long-term durability of a parallel-type Dye-Sensitized Solar Cell module using a platinum metal grid fabricated by direct current magnetron sputtering with heat treatment," Journal of Power Sources, vol. 222, pp. 333-339, 2013.

[153] H.-J. Kim, J.-D. Jeon, D. Y. Kim, J.-J. Lee, and S.-Y. Kwak, "Improved performance of Dye-Sensitized Solar Cells with compact $\mathrm{TiO}_{2}$ blocking layer prepared using low-temperature reactive ICP-assisted DC magnetron sputtering," Journal of Industrial and Engineering Chemistry, vol. 18, pp. 1807-1812, 2012.

[154] P. Chen and W. Y. Wu, "The use of sputter deposited TiN thin film as a surface conducting layer on the counter electrode of flexible plastic Dye-Sensitized Solar Cells," Surface and Coatings Technology, vol. 231, pp. 140-143, 2013.

[155] H. Wang, H. Li, J. Wang, and J. Wu, "High aspect-ratio transparent highly ordered titanium dioxide nanotube arrays and their performance in dye sensitized solar cells," Materials Letters, vol. 80, pp. 99-102, 2012.

[156] M. Awais, M. Rahman, J. M. Don MacElroy et al., "Deposition and characterization of $\mathrm{NiOx}$ coatings by magnetron sputtering for application in Dye-Sensitized Solar Cells," Surface and Coatings Technology, vol. 204, no. 16-17, pp. 2729-2736, 2010.

[157] L. Li, R. Chen, G. Jing, G. Zhang, F. Wu, and S. Chen, "Improved performance of $\mathrm{TiO}_{2}$ electrodes coated with $\mathrm{NiO}$ by magnetron sputtering for Dye-Sensitized Solar Cells," Applied Surface Science, vol. 256, no. 14, pp. 4533-4537, 2010.

[158] L. Meng, T. Ren, and C. Li, "The control of the diameter of the nanorods prepared by $\mathrm{dc}$ reactive magnetron sputtering and the applications for DSSC," Applied Surface Science, vol. 256, no. 11, pp. 3676-3682, 2010.

[159] V. Senthilkumar, M. Jayachandran, and C. Sanjeeviraja, "Preparation of anatase $\mathrm{TiO}_{2}$ thin films for Dye-Sensitized Solar Cells by DC reactive magnetron sputtering technique," Thin Solid Films, vol. 519, no. 3, pp. 991-994, 2010.

[160] S. Sutthana, N. Hongsith, and S. Choopun, "AZO/Ag/AZO multilayer films prepared by DC magnetron sputtering for DyeSensitized Solar Cell application," Current Applied Physics, vol. 10, no. 3, pp. 813-816, 2010.

[161] S. M. Waita, B. O. Aduda, J. M. Mwabora, G. A. Niklasson, C. G. Granqvist, and G. Boschloo, "Electrochemical characterization of $\mathrm{TiO}_{2}$ blocking layers prepared by reactive DC magnetron sputtering," Journal of Electroanalytical Chemistry, vol. 637, no. 1-2, pp. 79-83, 2009.

[162] M. F. Hossain, S. Biswas, T. Takahashi, Y. Kubota, and A. Fujishima, "Investigation of sputter-deposited $\mathrm{TiO}_{2}$ thin film for the fabrication of Dye-Sensitized Solar Cells," Thin Solid Films, vol. 516, no. 20, pp. 7149-7154, 2008.

[163] S. Wu, H. Han, Q. Tai et al., "Improvement in Dye-Sensitized Solar Cells employing $\mathrm{TiO}_{2}$ electrodes coated with $\mathrm{Al}_{2} \mathrm{O}_{3}$ by reactive direct current magnetron sputtering," Journal of Power Sources, vol. 182, no. 1, pp. 119-123, 2008.

[164] N. Hirahara, B. Onwona-Agyeman, and M. Nakao, "Preparation of $\mathrm{Al}$-doped $\mathrm{ZnO}$ thin films as transparent conductive substrate in Dye-Sensitized Solar Cell," Thin Solid Films, vol. 520, no. 6, pp. 2123-2127, 2012.

[165] Y.-S. Jin, K.-H. Kim, W.-J. Kim, K.-U. Jang, and H.-W. Choi, "The effect of RF-sputtered $\mathrm{TiO}_{2}$ passivating layer on the performance of dye sensitized solar cells," Ceramics International, vol. 38, no. 1, pp. S505-S509, 2012.

[166] G. Pérez-Hernández, A. Vega-Poot, I. Pérez-Juárez et al., “Effect of a compact $\mathrm{ZnO}$ interlayer on the performance of $\mathrm{ZnO}$-based Dye-Sensitized Solar Cells," Solar Energy Materials and Solar Cells, vol. 100, pp. 21-26, 2012.

[167] J.-A. Jeong and H.-K. Kim, “Thickness effect of RF sputtered $\mathrm{TiO}_{2}$ passivating layer on the performance of Dye-Sensitized Solar Cells," Solar Energy Materials and Solar Cells, vol. 95, no. 1, pp. 344-348, 2011.

[168] D.-J. Kwak, J.-H. Kim, B.-W. Park, Y.-M. Sung, M.-W. Park, and Y.-B. Choo, "Growth of $\mathrm{ZnO}$ :Al transparent conducting layer on polymer substrate for flexible film typed Dye-Sensitized Solar Cell," Current Applied Physics, vol. 10, no. 2, pp. S282-S285, 2010.

[169] S.-H. Paeng, M.-W. Park, and Y.-M. Sung, "Transparent conductive characteristics of Ti:ITO films deposited by RF magnetron sputtering at low substrate temperature," Surface and Coatings Technology, vol. 205, supplement 1, pp. S210-S215, 2010.

[170] H. K. Singh, D. C. Agarwal, P. M. Chavhan et al., "Study of swift heavy ion irradiation effect on indium tin oxide coated electrode for the Dye-Sensitized Solar Cell application," Nuclear Instruments and Methods in Physics Research B, vol. 268, no. 19, pp. 3223-3226, 2010. 
[171] L.-T. Huang, M.-C. Lin, M.-L. Chang, R.-R. Wang, and H.-C. Lin, "Thin film encapsulation of DSSCs on plastic substrate," Thin Solid Films, vol. 517, no. 14, pp. 4207-4210, 2009.

[172] B. Yoo, K. Kim, S. H. Lee, W. M. Kim, and N.-G. Park, "ITO/ATO $/ \mathrm{TiO}_{2}$ triple-layered transparent conducting substrates for Dye-Sensitized Solar Cells," Solar Energy Materials and Solar Cells, vol. 92, no. 8, pp. 873-877, 2008.

[173] J.-Y. Choi, J.-T. Hong, H. Seo et al., "Optimal series-parallel connection method of Dye-Sensitized Solar Cell for Pt thin film deposition using a radio frequency sputter system," Thin Solid Films, vol. 517, no. 2, pp. 963-966, 2008.

[174] S. H. Kang, M.-S. Kang, H.-S. Kim et al., "Columnar rutile $\mathrm{TiO}_{2}$ based Dye-Sensitized Solar Cells by radio-frequency magnetron sputtering," Journal of Power Sources, vol. 184, no. 1, pp. 331-335, 2008. 

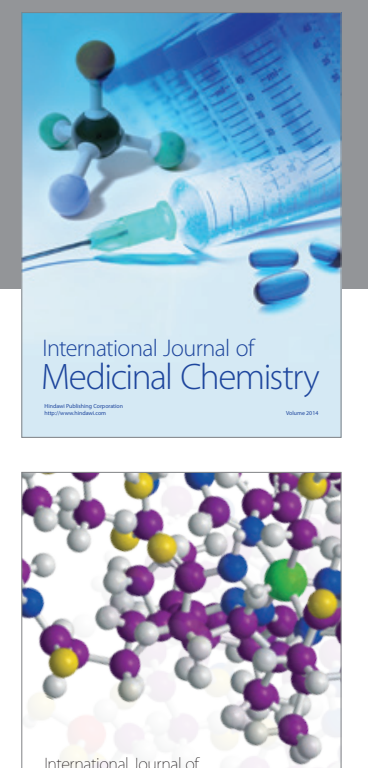

\section{Carbohydrate} Chemistry

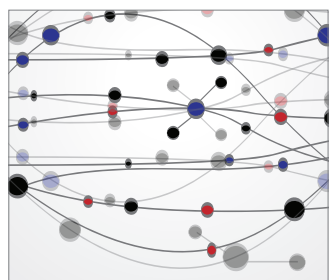

The Scientific World Journal
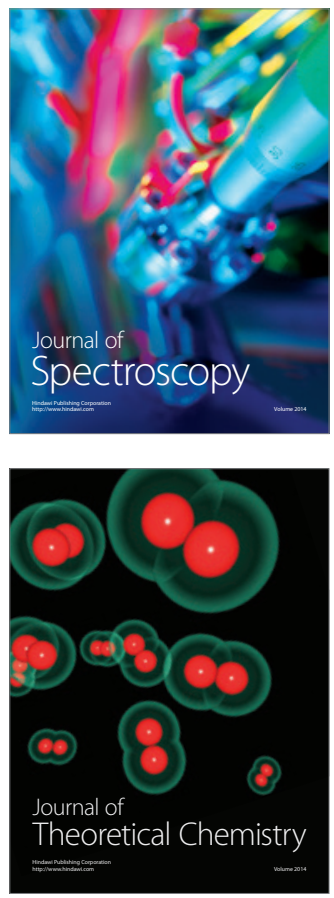
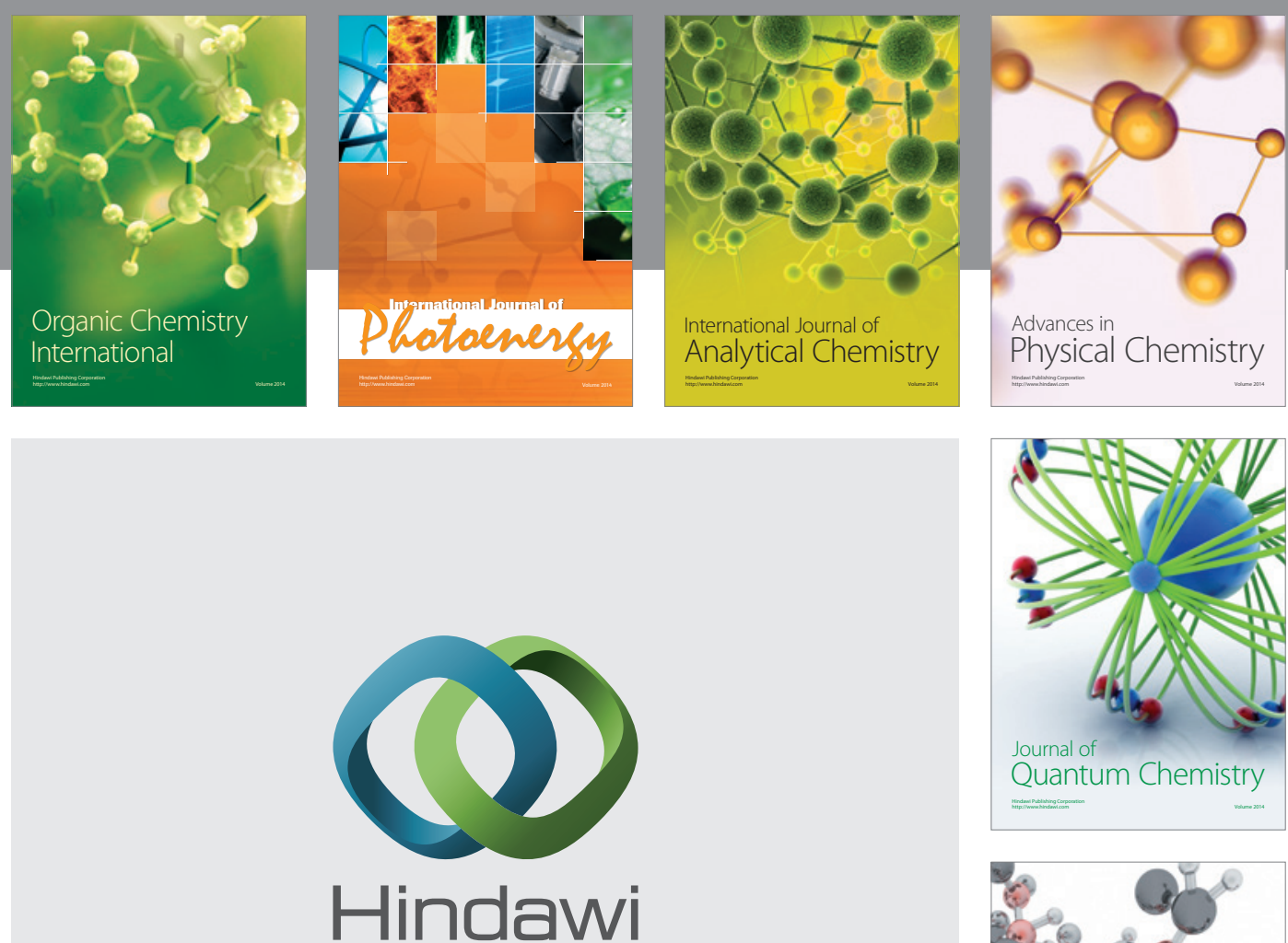

Submit your manuscripts at

http://www.hindawi.com

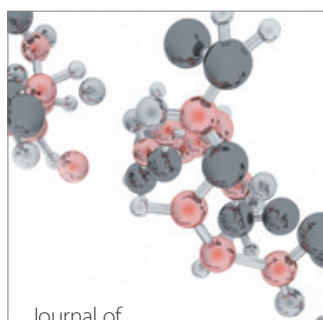

Analytical Methods

in Chemistry

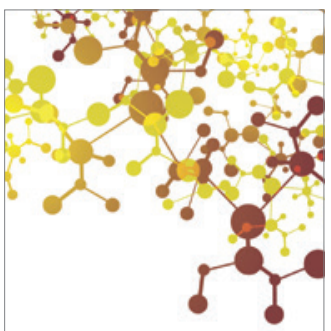

Journal of

Applied Chemistry

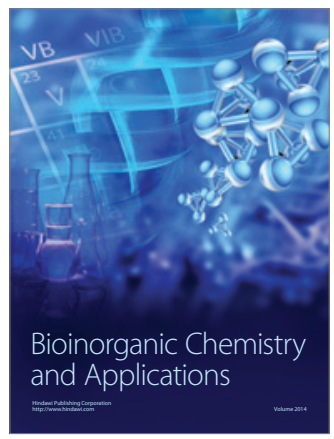

Inorganic Chemistry
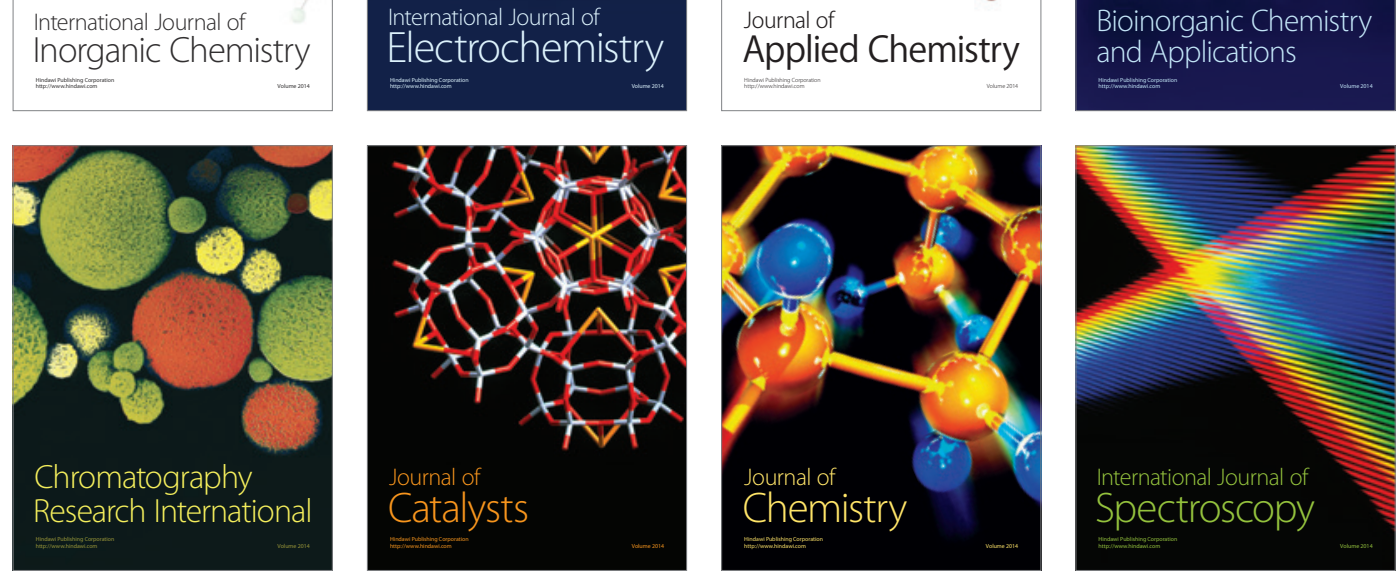